\title{
KRAMÁŘSKÉ TISKY JAKO SPECIFICKÝ DOKLAD KNIŽNÍ KULTURY 18. A 19. STOLETÍ. FOND KRAMÁŘSKÝCH TISKŮ MUZEA JINDŘICHOHRADECKA
}

\author{
Štěpánka Běhalová (Jindřichův Hradec)
}

\author{
Chapbooks as a Specific Example of the Book Culture of the 18th and 19th Centuries. The Collection of Chapbooks from the Museum of the Jindřichüv \\ Hradec Region
}

\begin{abstract}
This book-science study focuses on chapbooks, the development of research on this specific cultural phenomenon and the related collection activities, presented by the example of the collection of chapbooks housed in the Museum of the Jindrichův Hradec Region. Chapbooks have already been of scientific and collecting interest since the end of the 19th century. Extensive projects have recently been prepared with the aim of processing and providing access to the collections of memory and academic institutions. Bibliologically, a chapbook is defined as a small multi-page print, usually in octavo, duodecimo or sextodecimo (exceptionally trigesimo-secundo) format, which contained a lyric or epic text in poetry or prose with a religious or secular theme, was created with an emphasis on the commercial aspect and was primarily to make profit for the author, the printer (through the use of economical printing methods) as well as the seller (through the number of the printed copies sold).

In 2021, the collection of chapbooks, which is part of the holdings of the Museum of the Jindřichův Hradec Region, contains almost 4,400 inventory numbers. The collection was established in the 1930s, and further large acquisitions were made in the 1990s from the literary estate of the Landfras family of printers from Jindřichův Hradec. The collection is dominated by prints from the Jindřichův Hradec printing works, comprising more than half of the collection; a rather large set is formed by the production of Prague printing workshops (14\%); smaller sets come from printing workshops in Vienna, Chrudim and Jihlava. The earliest prints in the collection are Píseň o moci, divích a zázracích sv. Škapulíře [A Song about the Power, Wonders and Miracles of the Holy Scapular] (Hradec Králové 1725) and Dvě písničky nové velmi pěkné o svaté Anně [Two Very Nice New Songs about St Anne] (Příbram 1726). The latest prints come from the 1940s, namely Zásvětná modlitba k Panně Marii [A Dedication Prayer to the Virgin Mary] (Olomouc 1940) and Píseň k sv. Janu Nepomuckému [A Song to St John of Nepomuk] (J. Hradec 1944).

The study deals with the formal and content aspects of chapbooks. A comparison with extant wooden printing blocks from the inheritance of the Landfras printing works has revealed similarities in this printing decoration across printing workshops, but also the production of several apparently identical plates in one or more printing workshops especially in the 19th century. Moreover, the paper presents the changes in the decoration and form of the prints that chiefly occurred in the second half of the 19th century. In decoration, there is a clear connection with other types of printed production: in the area of secular themes with books of popular reading and in that of religious topics mainly with holy pictures, house blessings, memento mori prints and folding holy letters. There were certain analogies in their methods of production and decoration, but they were also distributed together and were among traditional means of personal devotion. The various texts printed in chapbooks (folk, popularised and artificial songs, poetry or prose texts of religious and secular content) can also be found in other printed media - in hymnals, songbooks, prayer books, books of folk reading, as well as theatrical plays, 19th-century almanacs, and periodicals. The chapbooks from the collection under study contain songs as well as other texts mostly related to religious pilgrimage in the 19th century, with the songs in them becoming ever less frequent.

The chapbook production of the long 19th century is represented in the collection by a large number of chapbooks from the Landfras printing works in Jindřichův Hradec. The Landfras family, whose publishing profile emphasised religious and prayer literature primarily for rural population, concentrated the production of chapbooks in this area as well.

The chapbook as a multidisciplinary phenomenon has been the subject of interdisciplinary research since the beginning of the 20th century. It has received the attention of ethnologists, librarians, book scientists and musicologists, as well as curators of collections in memory institutions. Its content and genre, hitherto studied in detail within secular broadside ballads, await evaluation by the new generation of literary scholars and cultural anthropologists in the field of religious chapbooks.
\end{abstract}

Keywords: chapbook - broadside ballad - chapbook holdings - chapbook collections - ethnology - book science - literary science - musicology - 19th century Museum of the Jindřichův Hradec Region - Landfras printing works

Více než staletá historie zájmu o kramářskou píseň a kramářský tisk zahrnuje vědeckou i sbírkotvornou činnost. Počátky sběratelského a odborného zájmu o kramářskou produkci sahají do konce 19. století. Pozornost jí věnoval pedagog, jazykovědec a etnograf František Bartoš, který jako první upřesnil pojmy kramářská poezie a kramářská píseň, ${ }^{1}$ těšila se zájmu Čeňka Zíbrta, až se dočkala edice v podobě antologie kramářských písní sestavené Miroslavem Novotným.

BARTOŠ $1871,1883,1885$. 
Ve 20. století pokračoval ve studiu kramářské písně historik, folklorista a muzikolog Robert Smetana ve spolupráci s literárním vědcem a estetikem Bedřichem Václavkem. ${ }^{2}$ Již v roce 1937 publikovali výbor kramářské poezie České pisně kramářské. Václavkovo jméno nesla i interdisciplinární Václavkova Olomouc, která byla v roce 1961 zaměřena právě na kramářskou píseň. ${ }^{3}$ Václavkovy a Smetanovy studie podnítily další zájem o tento fenomén, i když byl v období po druhé světové válce nadále zacílen ke světským tématům, tentokrát v souvislosti s politicky řízenou společenskou objednávkou. Literární věda, a to především na poli literární teorie, historie a také v oblasti ediční, věnuje nejčastěji pozornost kramářským písním. O jejich literární a etnologické ukotvení se zasloužil v poslední třetině 20. století především etnolog, folklorista a literární vědec, zaměřený na bádání o lidové slovesnosti Bohuslav Beneš. ${ }^{4}$

Značnou pozornost tomuto specifickému kulturnímu projevu věnoval např́iklad sběratel, maliŕ, grafik, ilustrátor, historik umění a etnograf Josef Václav Scheybal (19282001). ${ }^{5}$ Základ sbírky, založené v období první světové války, převzal od svého otce Josefa Scheybala st. Josef Václav Scheybal pak pokračoval ve sbírkotvorné činnosti ve druhé polovině 20. století. Dnes je celá sbírka čítající 10000 svazků uchována $\mathrm{s}$ další Scheybalovou pozůstalostí v Muzeu Českého ráje v Turnově. ${ }^{6}$ Scheybalovi se intenzivně zabývali odborným zpracováním sbírky a vzhledem $\mathrm{k}$ jejich detailní znalosti obsahu používali také dostupnou terminologii. Josef Václav Scheybal napsal v roce 1991: „, Otec sbíral kramářské tisky - letáky, písničky i celé špalíčky, uchovávané ve venkovských domácnostech mezi rodinnými památkami. V té době již vlastnil rozsáhlou, pečlivě upravenou a systematicky roztříěnou sbirku, která se každou vycházkou zvětšovala. "7 Druhým velkým soukromým sběratelem byl semilský archivár̆, pedagog a kronikář Rudolf Hlava (1911-1988), ${ }^{8}$ jehož sbírka je dnes součástí fondu Národního muzea.

Zájem o kramářské tisky nespočíval jen ve jmenovaných soukromých sbírkách, ale byl soustředěn také v pamětových institucích. V současné době jsou odborníkům známy rozsáhlé fondy kramářských tisků Národního muzea, Etnologického ústavu AV ČR v Praze, řady regionálních muzeí a v poslední době také nově zpracovávané soubory moravských institucí. Nejblíže s nimi souvisejí dochované soubory na Slovensku, v Mad'arsku, Polsku, Německu a Rakousku, dochází však ke srovnání také s fondy v Anglii, Francii nebo na americkém kontinentě.
Sběratelský zájem doprovázela snaha o uspořádání sbírek a jejich popis. Popis kramářských tisků jako tištěných médií byl směrován do oblasti bibliografického záznamu. Nejstarší tisky z veřejných i některých soukromých souborů se staly součástí celostátní unikátní bibliografie - Knihopisu českých a slovenských tisků od doby nejstarši až do konce 18. stoleti ${ }^{9}{ }^{9} \mathrm{v}$ němž tvoří téměř třetinu bibliografických záznamů, soustředěných pod heslo Píseň, Písnička, Písničky, Modlitba, Modlitby a další. ${ }^{10}$ Význam této jedinečné databáze pochopil sběratel Rudolf Hlava, který odpovídající část své sbírky do Knihopisu uložil, na rozdíl od Josefa Václava Scheybala, který se domníval, že tisk, který není uveden v Knihopisu, je cennější. ${ }^{11} \mathrm{Na}$ práce na Knihopise navázala práce na Národní retrospektivní bibliografii 19. století. Na základě zkušeností s rozsáhlými nepřehlednými soubory, které vznikly zařazením kramářských tisků do Knihopisu podle prvního substantiva $\mathrm{v}$ názvu, byla připravena samostatně národní retrospektivní bibliografie kramářských písňových tisků 19. století. Jejich objemná produkce byla katalogizována samostatně s možností respektování specifického charakteru. $\mathrm{V}$ nových pravidlech pro popis kramářských písňových tisků jako samostatných bibliografických jednotek byl akcentován incipit, který byl přepisován transliterací stejně jako text titulního listu, a následně byl transkribován podle soudobého pravopisu. Kromě dalších popisných údajů byl připojen též počet slok, názvy přítisků - dalších připojených písní a textů a rozměry zrcadla sazby. Za samostatnou jednotku, nikoliv za pouhou variantu, byl považován tisk, který měl stejný text, ale byl pořízen z jiného typu písma, odlišnou sazbou nebo měl podstatnou odchylku textu. Na specifika kramářského tisku jako tištěného média, a tedy popisné bibliografické jednotky upozornila záslužná práce Karla Bezděka a Evy Ryšavé. ${ }^{12}$ Použitím pojmu kramářský písňový tisk přispěli také $\mathrm{k}$ zásadnímu terminologickému uchopení pojmu v oblasti bibliografie, která je dnes v České republice především prostřednictvím existujících soupisů historických knižních fondů a jejich přesunu do digitálního prostředí jedním ze základních nástrojů vědeckého zhodnocení národní knižní kultury. $\mathrm{K}$ bibliografickým pilírưm (Knihopis českých a slovenských tisků od doby nejstarši až do konce 18. století dnes dostupný online, lístkový katalog Národní retrospektivní bibliografie kramářských písňových tisků 19. století budovaný v Knihovně Národního muzea v Praze, tištěná Bibliografia jarmočných a pútových tlači 18. a 19. storočia z územia Slovenska ${ }^{13}$ a Bibliografie cizojazyčných bohemikálních tisků do roku 1800$)^{14}$ se postupně

\footnotetext{
${ }^{2}$ VÁCLAVEK - SMETANA 1937, 1950; VÁCLAVEK 1947, 1963.

${ }^{3}$ VÁCLAVKOVA OLOMOUC 1961.

${ }^{4}$ BENEŠ 1970, 1983, 1995, 1998.

${ }^{5}$ SCHEYBAL 1991.

${ }^{6}$ MUZEUM ČESKÉHO RÁJE 2021a,b.

${ }^{7}$ SCHEYBAL 1991, s. 331.

${ }^{8}$ PROVENIO 2021.

${ }^{9}$ KNIHOPIS 1939-1967.

${ }^{10}$ KPS KNIHOPIS.

${ }^{11}$ ČERMÁKOVÁ 2017, s. 93.

${ }^{12}$ BEZDĚK - RYŠAVÁ 1983.

${ }^{13}$ BIBLIOGRAFIA 1996.

${ }^{14}$ BCBT 2016.
} 
přidaly další specializované databáze a soupisy jednotlivých fondů, mnohdy vznikající jako součást rozsáhlých vědeckých projekti̊. V oblasti kramářských tisků je dokončen projekt Internetová databáze kramářských tisků Etnologického ústavu Akademie věd České republiky v Praze ${ }^{15}$ a tiskem vydaný katalog kramářských tisků. ${ }^{16}$ Průběžně se obohacuje internetová knihovna Špalíček ${ }^{17}$ s digitálními kopiemi kramářských tisků ze 17.-19. století budovaná v Knihovně Národního muzea. ${ }^{18}$ Její součástí je obsažná výběrová bibliografie ${ }^{19}$ ke kramářským, poutním, historickým, politickým, prorockým a zlidovělým písním, jejich výzdobě, dále ke skladbám lidových písmáků, také $\mathrm{k}$ autorům, interpretům, distributorům a sběratelům písní a $\mathrm{k}$ tiskárnám, které tento typ tisků vydávaly.

Očekávané jsou rovněž výsledky v současné době probíhajícího projektu NAKI Kramářské písně v brněnských historických fondech, jehož hlavním řešitelem je Filozofická fakulta Masarykovy univerzity v Brně ve spolupráci s Moravskou zemskou knihovnou, Moravským zemským muzeem a Etnologickým ústavem AV ČR. Jeho cílem je „přispět k uchování, prezentaci a využití kramářských pisní jako textových útvarů pololidové literatury. Jeho součástí je zpracování 17000 kramářských písní z obdobi 17.-19. století z fondi̊ Moravské zemské knihovny v Brně, brněnského oddéleni Etnologického ústavu AV ČR a Etnografického ústavu Moravského zemského muzea. "20

Důsledkem multidisciplinárního zájmu o kramářskou produkci je zřetelné kolísání prŕístupu v oblasti používání termínů kramářský tisk a kramářská píseň a jejich chápání jednotlivými vědními obory. Literární věda a muzikologie hovoří nejčastěji o kramářských písních, at' již pojímaných žánrově jako pololidová literárně-písňová tvorba, či sbírkotvorně. ${ }^{21}$ Většina definic má původ v kramářské písni jako literárním žánru, sleduje ale též vnější podobu a funkci kramářského tisku. Použití pojmu kramářská píseň zvláště při průzkumech fondů kramářských tisků souvisejících s poutnictvím, které mají tutéž vnější podobu, ale obsahují např́iklad nepísňový text, přivádí badatele při použití pojmu kramářská píseň do slepé uličky. Nejasná situace vrcholí při zjištění, že v tištěném médiu - kramářském tisku - označeném jako „kramářská píseň“ - se nalézá např. text modlitby. Tato zjištění vedou k opakovaně probíhající debatě nových badatelů nad definicemi a užitím pojmů. Autoři bibliografických, knihovědných a etnografických příspěvků týkajících se kramářské produkce a také kurátoři sbírkových fondů pamětových institucí, kteří pečují o sbírkové soubory, užívají termín kramářský tisk, př́padně kramářských písňový tisk. ${ }^{22}$
Pojem kramářská píseň zde bývá užit v užším významu v souvislosti s literárním žánrem.

Užití termínu kramářský tisk pro tištěné médium se jeví jako velmi jednoduché, stejně jako bylo zcela intuitivní zařazení těchto tisků s různými typy textů (modlitby, písně, litanie) v jednom konkrétním doma vyrobeném špalíčku. Zde jsou za sebou řazeny písně se světskou tematikou, a to jak typické kramářské balady, tak písně lyrické, dále písně s náboženskou tematikou, např. poutní, a navíc jsou přidány na pohled totožné tisky s modlitbami a litaniemi. U některých písní jsou uvedeni více či méně známí autoři, jiné lze přiřadit do kancionálové tvorby, u dalších je patrný jejich lidový původ.

Pro aktuální řešení terminologické otázky v oblasti knihovědy, ale též etnologie a správy fondů pamět'ových institucí, je možné využít především závěry vzniklé při vytváření pravidel pro popis kramářských písňových tisků a jeho další rozvoj.

Kramářský tisk je pro tyto účely definován jako drobný několikastránkový tisk většinou osmerkového, dvanácterkového i šestnácterkového (výjimečně dvaatřicetinkového) formátu, který obsahuje lyrický nebo epický text v poezii či v próze s náboženskou či světskou tematikou, při jehož vzniku byla upřednostněna obchodní stránka a byl sledován především výdělek autora, tiskaře (používáním úsporných metod tisku) i prodejce (množstvím prodaných tisků). ${ }^{23}$ Lidé si kramářské tisky kupovali na náboženských poutích a jarmarcích, kde se prodával v krámech, na tržních stáncích nebo při kolportáži na ulicích, dvorech či po vsích. Někdy text slyšeli nejdříve z úst vůdce náboženského procesí nebo jarmarečního prodavače, který jej zároveň prrítomným prodával. Levný tisk si pak odnášeli domů, kde jej ukládali samostatně pospolu, někdy je vkládali do modlitebních knih, lepili na víka truhel či na vnitřní strany dveří skříní nebo si z jednotlivých tisků vytvářeli tzv. špalíčky - doma šité knihy, k nimž další nově získané tisky prrišívali. Různorodé texty z kramářských tisků si pak četli, zpívali nebo je deklamovali. Některým tiskům prrisuzovali také ochrannou moc v nemoci, nepřízni počasí, válce a dalších životních nesnázích, která spočívala ve vlastnictví samotného tisku včetně ilustrace i v deklamování nebo zpěvu slov jeho textu. Zvláštní druh tzv. pověrečných kramářských tisků dokonce nosili stále při sobě. Obsahem tohoto druhu tištěného média byl krátký žánrově značně různorodý literární útvar, nejčastěji světská či náboženská píseň, modlitba nebo krátký epický text. Používaná vnější podoba tisku ve spojení s obsahem vytváŕí z tohoto tištěného média samostatnou specifickou součást knižní kultury především 18. a 19. století.

\footnotetext{
${ }^{15}$ HOLUBOVÁ $2017 \mathrm{~b}$.

${ }^{16}$ HOLUBOVÁ - KOPALOVÁ 2008; HOLUBOVÁ 2012, 2017a.

${ }^{17}$ ŠPALÍČEK.

${ }^{18}$ BYDŽOVSKÁ 2012.

19 ŠPALÍČEK - Výběrová bibliografie.

${ }^{20}$ KRAMÁŘSKÉ PÍSNĚ BRNO 2019-2022.

${ }^{21}$ BENEŠ 1998, s. 79.

${ }^{22}$ RYŠAVÁ 1998a, s. 25-28; RYŠAVÁ 1998b, s. 58-60; VEČERKOVÁ 1998, s. 84-92; FIRSTOVÁ 1998, s. 93-96.

${ }^{23}$ V př́ispěvku je užíván termín kramářský tisk jako druh tišstěného média. Více viz BĚHALOVÁ 2001, 2003, 2013, 2017. SMETANA - VÁCLAVEK 1937; VÁCLAVKOVA OLOMOUC 1961; RYŠAVÁ - BEZDĚK 1983; VEČERKOVÁ 1995, 1998; TISKÁRNY A TISKY 19. STOLETÍ 1998; LIDOVÁ KULTURA 2007; HOLUBOVÁ 2008.
} 
Fond Kramářské tisky, který je součástí Sbírky Muzea Jindřichohradecka (dále KT MJH), byl utvářen již od 30. let 20. století, kdy již působil $\mathrm{v}$ jindřichohradeckém muzeu profesor jindřichohradeckého gymnázia, správce muzejních sbírek a pozdější ředitel muzea PhDr. Jan Muk, ${ }^{24}$ který byl v úzkém kontaktu s majiteli jindřichohradecké Landfrasovy tiskárny. ${ }^{25}$ Po náhlém úmrtí Viléma Bohumila Landfrase v roce 1931 vypomáhal v redakci místního týdeníku Ohlas od Nežárky a spolupracoval s vdovou Marií Landfrasovou a její dcerou provdanou Jiráčkovou. ${ }^{26}$ Do muzea $v$ té době převzal $\mathrm{k}$ již existujícím souborům památek na Landfrasovu tiskárnu řadu dalších předmětů, $\mathrm{k}$ nimž patřily i v tiskárně již nepoužívané původní dřevěné štočky a soubor jindřichohradeckých tisků včetně tisků kramářských. V roce 1940 publikoval Jan Muk v týdeníku Ohlas od Nežárky studii o špalíčkových a jarmarečních písničkách ,, tištěných u Landfrasu a prodávaných na poutich a výročnich trzích snad všude, kde mluvilo se českým jazykem ". ${ }^{27} \mathrm{Z}$ původních 85 písní byla celkem 21 milostná píseň, dále dvě písně zabývající se podivuhodnými a zajímavými událostmi a tři písně dobrodružné, následovaly písně $\mathrm{s}$ náboženským tématem a písně vlastenecké. Ve sbírkotvorné předválečné činnosti Jana Muka lze spatřovat počátky fondu Kramářské tisky, který obsahuje k roku 2021 téměř 4400 inventárních čísel. Jeho součástí je také šest dobových konvolutů kramářských tisků, tzv. špalíčků, které zvyšují počet ve fondu uložených kramářských tisků o další 104 kusy tisků. Nejrozsáhlejší nové akvizice pocházejí z pozůstalosti Landfrasovy tiskárny zakoupené v roce 1996 a 1997, další, menší soubory byly získány sběrem nebo darem především od zdejších sběratelů. Před rokem 2010 bylo restaurováno téměř 800 nejpoškozenějších kramářských tisků souboru a jednotlivé kramářské tisky jsou uloženy samostatně $\mathrm{v}$ nekyselých ochranných obalech a kompletně naskenovány. $\mathrm{V}$ roce 2013 byla připravena výstava a publikace Pozdvihni se duše z prachu..., která prezentovala náboženský kramářský tisk z této sbírky. ${ }^{28}$

Další památky na Landfrasovu tiskárnu jsou zařazeny ve fondech Jindřichohradecké tisky, ${ }^{29}$ Knižní kultura, ${ }^{30}$ Tiskařské štočky ${ }^{31}$ a Jiné tisky. ${ }^{32}$ Kromě sbírkových předmětů získávaných od založení muzea $\mathrm{v}$ roce 1882 a sbírek získaných Janem Mukem je stejně jako v případě fondu Kramářské tisky obohatila významná akvizice od potomků rodiny Landfrasů uskutečněná $\mathrm{v} 90$. letech minulého století. Jednalo se nejen o vlastní tisky této tiskárny, ale též o tisky z jiných tiskáren. Je možné předpokládat, že s nimi Landfrasové pracovali při pořizování vlastních nákladů kramářských tisků. $V$ rámci těchto fondů bylo provedeno několik analytických knihovědných sond souvisejících s proveniencí, datací, typologicko-typografickou úpravou a jazykovou a obsahovou stránkou kramářských tisků.

Z hlediska tiskařské provenience byla více než polovina tisků $\mathrm{z}$ fondu KT MJH tištěna $\mathrm{v}$ Jindřichově Hradci, $14 \%$ tisků je z pražských tiskáren. Další místa tisku jsou zastoupena pouze desítkami tisků, a to Vídeň dvěma procenty, dále jedním procentem Chrudim a Jihlava a více než 10 tisků se ve sbírce dochovalo z Litomyšle, Kutné Hory, Českých Budějovic a Znojma. Pouhými několika tisky je zastoupeno Brno, Bratislava, Čáslav, Hradec Králové, Innsbruck, Linec, Olomouc, Pardubice, Písek, Př́bram, Slaný a Skalica. Ojediněle se na tiscích objevují i tato místa: Břevnov, Freiburg, Frýdek Místek, Gratz, Holešov, Cheb, Kladsko, Klatovy, Mladá Boleslav, New York, Opava, Sankt Pölten, Tarnov, Uherská Bystřice, Vackovice a Žitava. Chybějící nebo neurčité impresum se vyskytuje u celkem $13 \%$ tisků, častá je formulace ,Vytištěná roku tohoto " nebo pouze „Roku tohoto" objevující se nejčastěji na přelomu 18. a 19. století.

Téměř polovina kramářských tisků ve fondu jindřichohradeckého muzea není datována. Pokud je rok uveden, nejčastěji je tomu tak u tisků z jindřichohradecké Landfrasovy tiskárny z období 1848-1868, přesné datace jsou uváděny již v 18. století. Mezi nejstarší tisky fondu se řadí královéhradecký Tibelliův tisk Píseñ o moci, divích a zázracích sv. Škapulíre z roku 1725 a príbramský tisk Dvě pisničky nové velmi pěkné o svaté Anně z roku 1726.

Nejmladší písně pak svou datací sahají až do poloviny 20. století, kdy byla napríklad v roce 1940 tištěna v Olomouci Zásvětná modlitba k Panně Marii, pomocnici

\footnotetext{
${ }^{24} \mathrm{PhDr}$. Jan Muk (6. 1. 1901 - 20. 5. 1980), jindřichohradecký rodák, absolvent Filozofické fakulty Univerzity Karlovy v oboru dějepis, zeměpis působil od roku 1927 trvale v Jindřichově Hradci na gymnáziu, byl jednatelem kuratoria a od roku 1934 správcem jindřichohradeckého muzea, kterému vtisk1 kulturněhistorický a regionální charakter činnosti. Intenzivně se věnoval pedagogické, historické a muzejní práci, spravoval městský archiv, vedl městskou kroniku, byl předsedou spolku Přátelé starého Jindřichova Hradce, konzervátorem památkové péče a pracoval v redakci Ohlasu od Nežárky. Politicky se angažoval ve straně národně demokratické a po válce ve straně socialistické. BËHALOVÁ - FÜRBACH 2015, s. 37.

${ }^{25}$ BĚHALOVÁ 2018.

${ }^{26}$ Vilém Bohumil Landfras (19. 8. 1865 - 23. 7. 1931) vedl tiskárnu po smrti svého otce Viléma Antonína Landfrase (19. 5. 1830 - 1. 6. 1902), který navázal na činnost svých předků, děda Josefa Landfrase (6.3.1769 - 5. 8. 1840) a otce Aloise Landfrase (25. 4. 1797 - 9. 5. 1875). Po smrti Viléma Bohumila Landfrase převzala tiskárnu i redakci Ohlasu od Nežárky jeho žena Marie Landfrasová rozená Matoušková (2. 10. 1871 - 15. 11. 1975) se svou dcerou provdanou Jiráčkovou (30.11. $1905-1.12 .1995)$. V roce 1940 ji pronajali nájemci Františku Pfauserovi. S Janem Mukem úzce spolupracovali a díky tomu byly do tehdejšího městského muzea získány zajímavé soubory tisků, archiválií, fotografií, štočků i trojrozměrných předmětů připomínající činnost tiskárny. BĚHALOVÁ - FÜRBACH 2015, s. 56.

${ }^{27}$ MUK 1940a; MUK 1940b. Autor aktuálně reagoval na tehdejší zvýšený odborný zájem, který byl „písňovým jarmarečním tiskům“ věnován v Národním muzeu, kde byl založen ve 30. letech 20. století rozsáhlý fond těchto tiskủ. ŠPALÍČEK 1940.

${ }^{28}$ BĚHALOVÁ 2013.

${ }^{29}$ Fond obsahuje téměř 3700 tisků z jindřichohradeckých tiskáren od 18. do 20. století. Největší soubor tvoří tisky z Landfrasovy tiskárny, k nimž patří kromě náboženské a lidové zábavné literatury také literatura vzdělávací, vlastivědná, historická a periodická.

${ }^{30}$ Fond obsahuje veškeré neknižní dokumenty týkající se činnosti jindřichohradeckých tiskáren, nakladatelství, knihařství a knihkupectví, ale také zdejších autorů, redakcí novin a podobně. V současné době převažují mezi téměř 1000 inventárními čísly památky na Landfrasovu tiskárnu.

${ }^{31}$ Fond soustřed’uje přes 2000 štočků z regionálních tiskáren z období 19. a 20. století. Jeho nejcennější částí je soubor historických dřevěných a kovových štočků z bývalé jindřichohradecké Landfrasovy tiskárny.

${ }^{32}$ Fond obsahuje přes 400 položek různých tiskovin, často s rukopisnými vpisky, především z regionu Jindřichohradecka. Zahrnuje plakáty, diplomy, pamětní listy, pozvánky a další př́iležitostné tiskoviny včetně souboru tanečních pořádků z 19. a 20. století.
} 


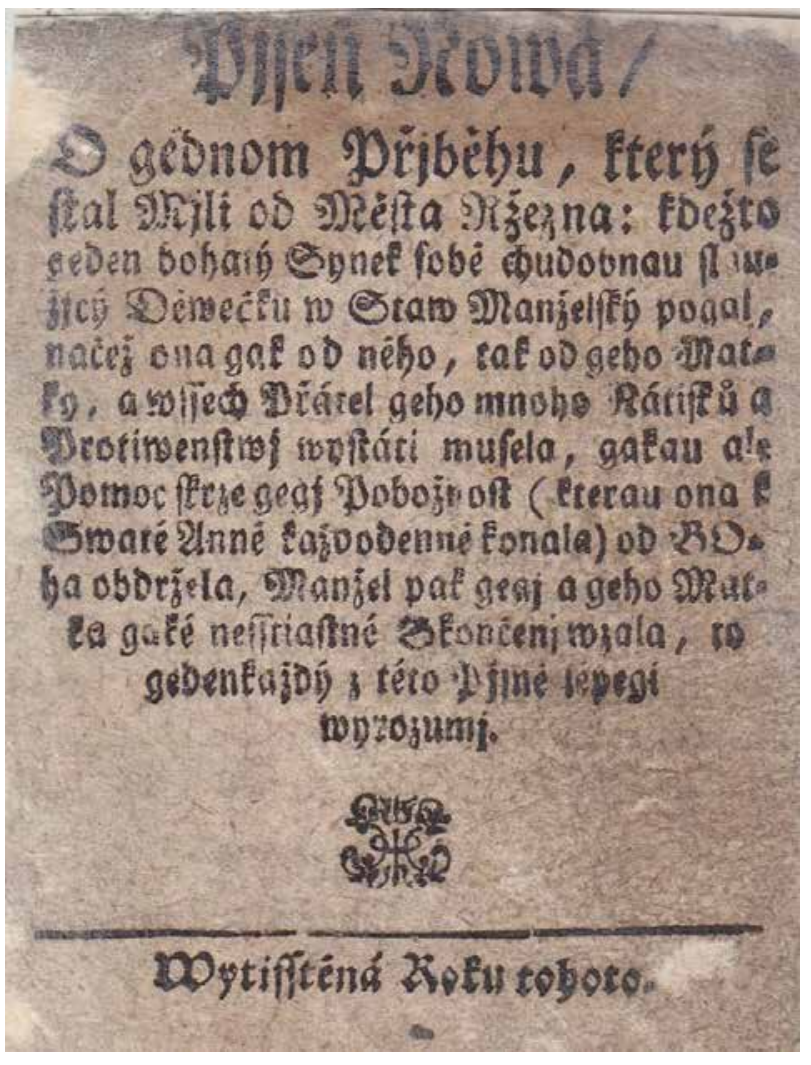

Obr. 1. Píseň nová o jednom př́běhu, který se stal míli od města Řezna. [Česko, s. n., po 1777]. 2 s. doch., $113 \times 87 \mathrm{~mm}$. Incipit: Žalostivou věc divnou, lidé poslouchejte. Nápěv: Černět já se přistrojím. Sbírka MJH, K 4603.

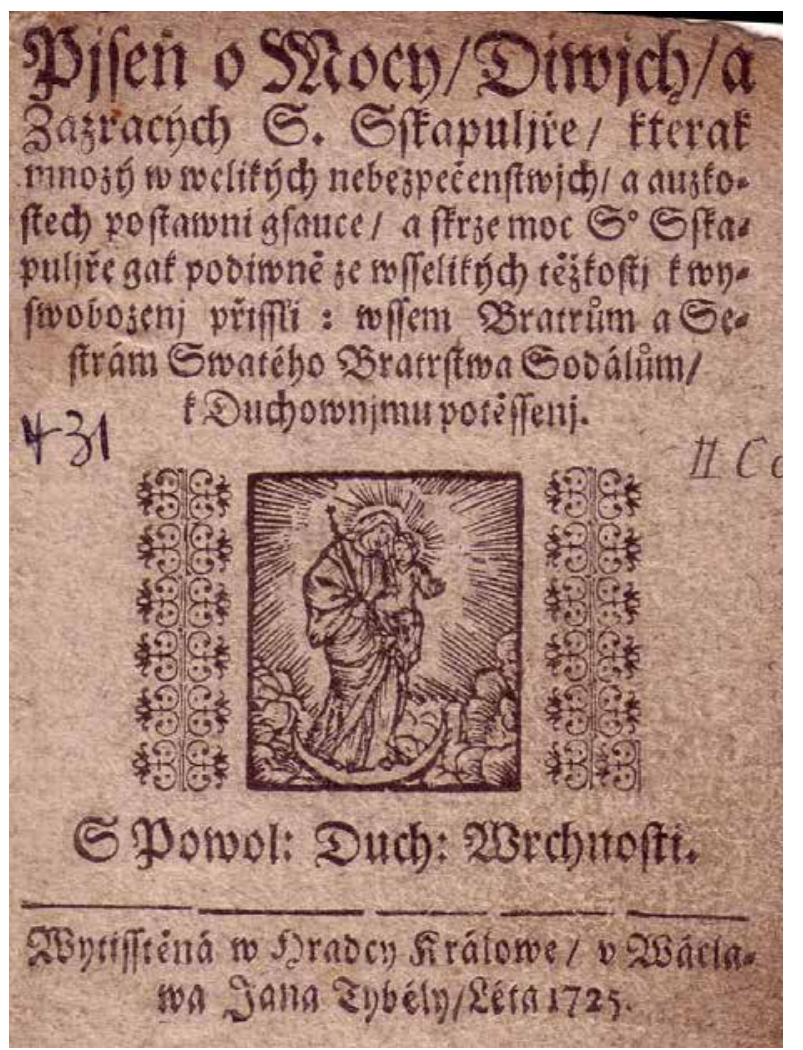

Obr. 3. Píseň o moci, divích a zázracích sv. škapuliře. Hradec Králové, Václav Jan Tibelli, 1725.8 s., $103 \times 85$ mm. Incipit: Raduj se křestane z toho daru. Nápěv: Z hlubokosti v mé těžkosti. Sbírka $\mathrm{MJH}, \mathrm{K} 4851$.

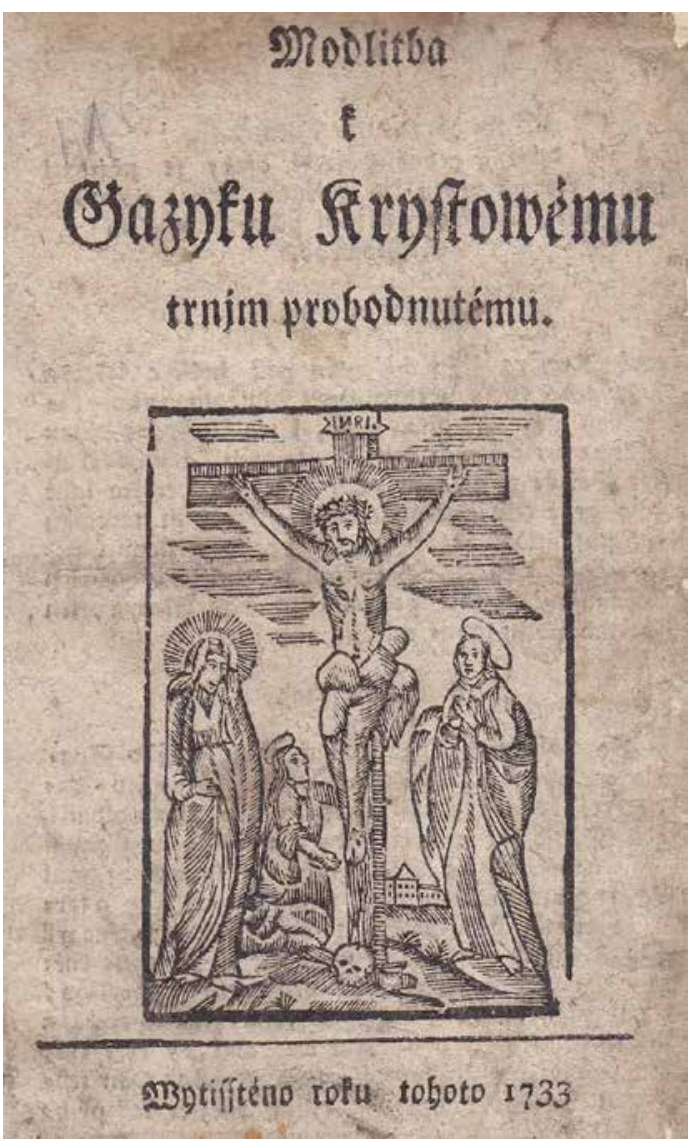

Obr. 2. Modlitba k jazyku Kristovému. [Česko, s. n.] 1733. 4 s., $140 \times 90$ mm. Incipit: Dvojí tajné umučení. Sbírka MJH, K 4169.

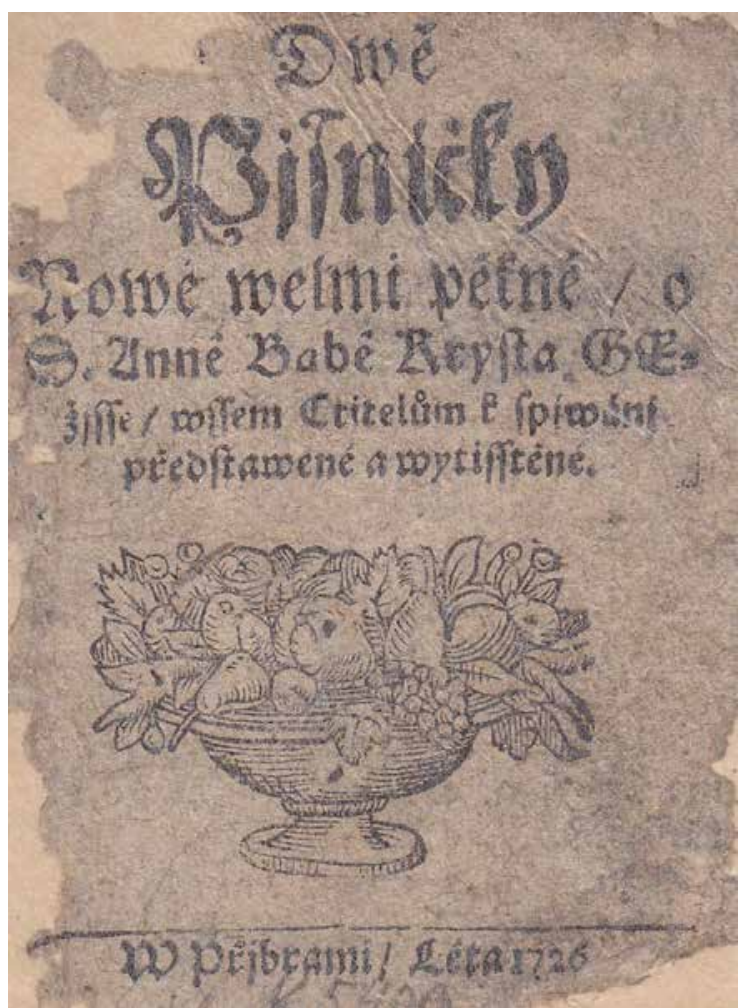

Obr. 4. Dvě písničky nové velmi pěkné o $\mathrm{s}$. Anně, bábě Krista Ježíše. Př́bram, s. n., 1726.8 s., $104 \times 89$ mm. Incipit 1: Budiž pozdravená matičko Anno svatá. Nápěv: Smutná lamenta. Incipit: Sem s chvátáním pospíchejte. Nápěv: Žádný mě již neuhasí. Sbírka MJH, K 5400. 
křest’anů. V souboru jindřichohradeckých kramářských tisků jsou dochovány ojedinělé exempláře jindřichohradeckých tisků z první poloviny 18. století, nejstarší Písně dvě nové, první k svatému Janu Nepomuckému. Druhá Ježiši, Marii a Josefu z roku 1733 vznikla pravděpodobně v tiskárně Jana Bedřicha Jakeše, Píseň nová pravdivá je z dílny Františka Antonína Schönsteina z roku 1737, několik tisků z tiskárny Františka Petra Hilgartnera (1737-1750), několik desítek tisků z období působení jeho syna Ignáce Vojtěcha Hilgartnera (1757-1793). Zajímavý soubor blíže tiskařsky ani vročením neurčených jindřichohradeckých tisků pochází z období přelomu 18. a 19. století. Po převzetí tiskárny v roce 1797 uváděl tiskař Josef Landfras v impresu své jméno, přesnou dataci připojoval nejčastěji mezi lety 1810 a 1820 . Další přesnější datace se na kramářských tiscích z Landfrasovy tiskárny objevily ve 40. letech a nejvíce tisků má přesnou dataci z 50. a 60. let 19. století. Z konce 19. století se dochovaly lyrické písně s regionálními motivy, např́klad Kaplička u Nežárky, z přelomu 19. a 20. století satirické písně mírící například ke stavbě zdejší nové poštovní budovy nebo žertovná píseň k vepřovým hodům. Ojedinělé kramářské tisky 20. století jsou zaměřeny na slavnostní svěcení nových zvonů v Jindřichově Hradci v roce 1929 a drobné tisky s písněmi a modlitbami tiskla také nově založená jindřichohradecká Alexandrova tiskárna. Nejmladší je píseň s tematikou sv. Jana Nepomuckého z roku 1944.

Způsob uvedení údajů o jejich vydání na kramářských tiscích ovlivňovala císařská i církevní nařízení, která se týkala jak stránky tiskové, tak v prŕípadě kramářských tisků také způsobu šíření prostřednictvím kramářského či podomního prodeje. Dozor nad prodejem tiskovin na jarmarcích i ulicích byl zaváděn opakovaně již od počátku 17. století, kulminoval v období josefínských nařízení a dále ve dvorských dekretech Františka I. týkajících se volného šíření letáků. ${ }^{33}$ Aktuální opatření se u drobných tisků, mezi něž patřily i kramářské tisky, často obcházela, údaje o vydání a roku vytištění se na tisku neuváděly, což znemožňovalo postih tiskařů.

Jakkoliv se kramářské tisky vyznačují uvedenými specifiky v oblasti uvádění impresa, jejich nejpatrnějším společným rysem je výrazná formální podoba, díky níž byly svazovány do špalíčků nebo soustředěny do sběratelských kolekcí a sbírkových fondů.

Tento drobný několikastránkový tisk byl tištěn na levném ručním dřevitém a později strojově vyráběném papíru levnou sazbou z větších typů písma, nejčastěji švabachem, v 19. století pak i antikvou. Z vizualizačního a evidenčního aparátu byly v kramářských tiscích užívány iniciály, archové signatury, kustody. Č́slování stran bylo užito výjimečně. Text byl členěn rubrikami mezi strofami písní nebo jejich číslováním, jiné typy textů byly členěny nadpisy částí sázenými odlišným typem nebo větším písmem. V kramářských tiscích se využívala také většina levných a dostupných prvků dekoru. Obvyklé bylo používání jednoduchých i ozdobných linek, vinět složených z kombinace typografických ozdob a vlysů. Jednotlivé exempláře sestávaly z volných listů a nebyly opatřeny žádnou vazbou, takže při prodeji měl titulní list zcela výjimečnou úlohu. Spočívala v jeho ustálené unifikované podobě, kterou tvořil formalizovaný a víceméně stereotypní název a impresum, at' již bylo uvedeno v úplné, či neúplné podobě, do konce 18 . století bylo součástí titulního listu také uvedení incipitu a nápěvu. Výjimečně byla na druhé straně uvedena cenzura a text začínal až na straně následující. V 19. století bývají incipit a nápěv uváděny řidčeji, a to většinou na druhé straně v záhlaví textu, zatímco titulní list rámovaly jednoduché i ozdobné rámečky, mnohdy jediné na první pohled patrné rozlišení mezi jednotlivými vydáními.

Zajímavou složkou ustálené formální podoby titulního listu kramářských tisků byla výzdoba $\mathrm{v}$ podobě otisku štočku informačního charakteru nebo viněty. Tato výzdoba umístěná mezi názvem a impresem navozovala téma textu a poutala pozornost kupujících, zrrídka se jednalo o ilustraci př́mo zhotovenou ke konkrétnímu titulu kramářského tisku. Průkopnickou monografickou prací je v tomto ohledu třísvazkový Katalog kramářských tisků Etnologického ústavu v Praze, který ve druhém díle přinesl rozbor vyobrazení $\mathrm{s}$ tematikou biblické a křest’anské ikonografie $\mathrm{s}$ téměř osmi sty obrázky titulních listů. ${ }^{34}$

Sbírka Muzea Jindřichohradecka poskytuje pro studium obrazových př́loh kramářských tisků výjimečné možnosti odborné práce s původním materiálem, spočívající v porovnání vyobrazení na kramářských tiscích s fondy Tiskařské štočky, Knižní kultura a Jindřichohradecké tisky. Analytické sondy v oblasti štočkové výzdoby upřesnily dosud uváděné informace o výbavě tiskáren štočky a jejich migraci mezi tiskárnami, ale odhalily i zcela nové skutečnosti o výrobě podobných či stejných štočků, užívané v jedné nebo ve více tiskárnách. ${ }^{35}$

Napríklad v oblasti svatojanské tematiky bylo ve fondu Tiskařské štočky nalezeno celkem 10 štočků z pozůstalosti jindřichohradecké Landfrasovy tiskárny, k nimž byly doloženy otisky na kramářských tiscích z jindřichohradeckých i dalších tiskáren. ${ }^{36}$ Štoček s poloviční postavou sv. Jana Nepomuckého na mostě se svatozář́ a pěti hvězdičkami je otištěn na třech tiscích, na nichž lze sledovat postupné opotřebení štočku se stále zřetelnější prasklinou a zařadit tisky časově za sebou. Největší poškození vykazuje štoček otištěný na pražské Nábožné písni $k$ svatému Janu Nepomuckému, méně poškozený otisk se nachází na nedatované Nábožné modlitbě $k$ svatému Janu Nepomuckému a na jindřichohradeckém výtisku Svatojánské pobožnosti datované do roku 1810. Exemplář štočku byl tedy nejprve používán v Landfrasově tiskárně a poté v pražské tiskárně, odkud se originál vrátil zpět do jindřichohradecké tiskárny. Nejstarší otisk štočku znázorňujícího oválný medailonek se sv. Janem Nepomuckým z pozůstalosti Landfrasovy tiskárny je doložen na Nábožné písni k svatému Janu Nepomuckému

\footnotetext{
${ }^{33}$ WÖGERBAUER et al. 2015.

${ }^{34}$ HOLUBOVÁ 2012.

${ }^{35}$ BĚHALOVÁ 1993, 1994, 1995, 1996a, b, 1997.

${ }^{36}$ BĚHALOVÁ 1993, s. 23.
} 


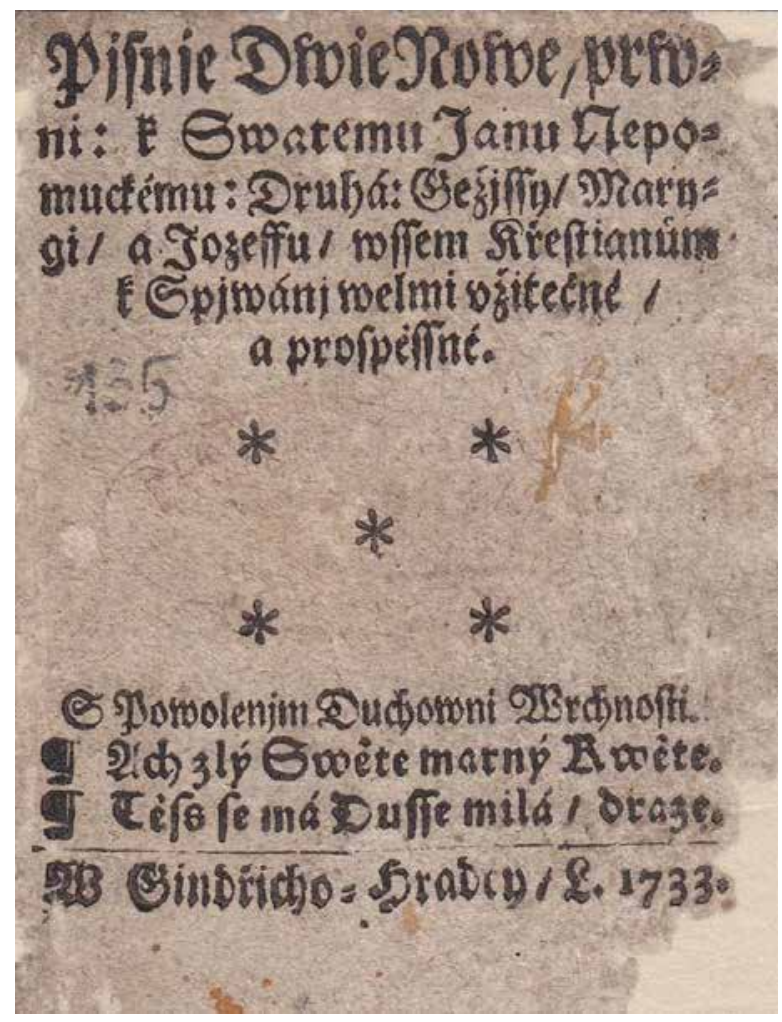

Obr. 5. Písně dvě nové, první: k svatému Janu Nepomuckému. Druhá: Ježíši, Marii, Josefu. Jindřichův Hradec, s. n., 1733. 6 s. doch., $98 \times 76 \mathrm{~mm}$. Incipit 1: Ach zlý světe. Nápěv: O lásko, lásko, lásko má. Incipit 2: Sem s chvátáním pospíchejte. Nápěv 2: Žádný mě již neuhasí. Sbírka MJH, K 3816.

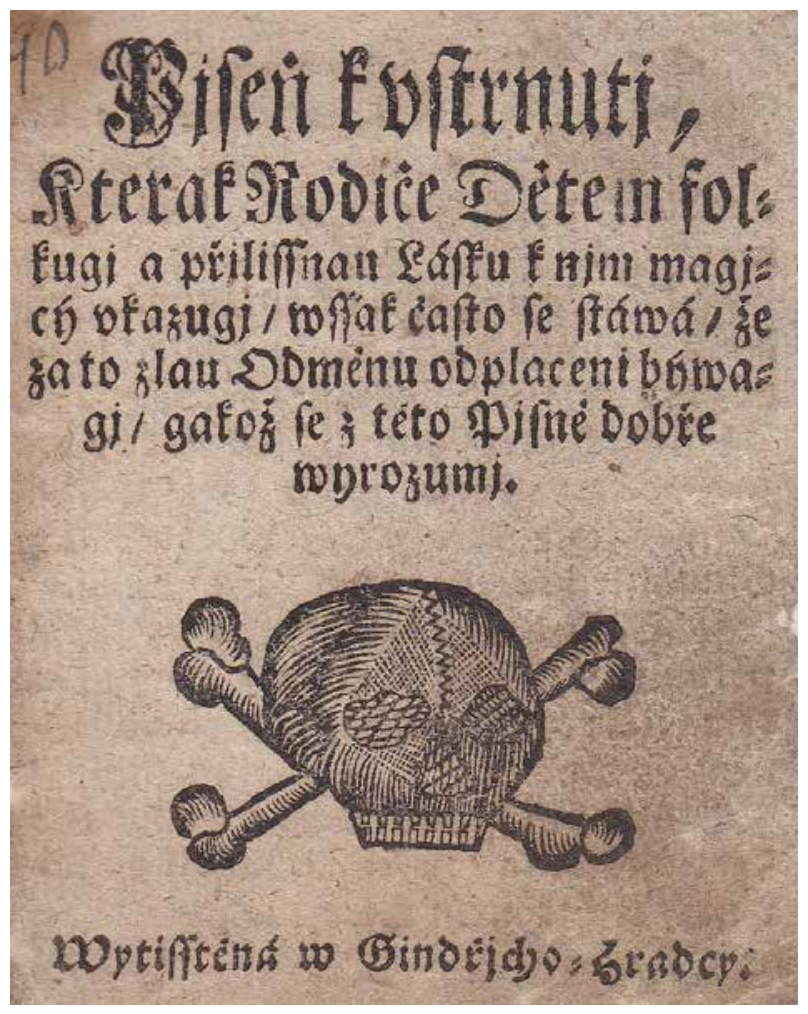

Obr. 7. Píseň k ustrnutí, kterak rodiče dětem folkují a př́lišnou lásku mající ukazují, však často se stává, že za to zlou odměnu odplaceni bývají, jakož se z této písně dobře vyrozumí. J. Hradec, [s. n., druhá polovina 18. století]. 8 s., $94 \times 82$ mm. Incipit: Poslyšte milí křest’ané. Nápěv: Žalostně budu zpívati. Sbírka MJH, K 3221.

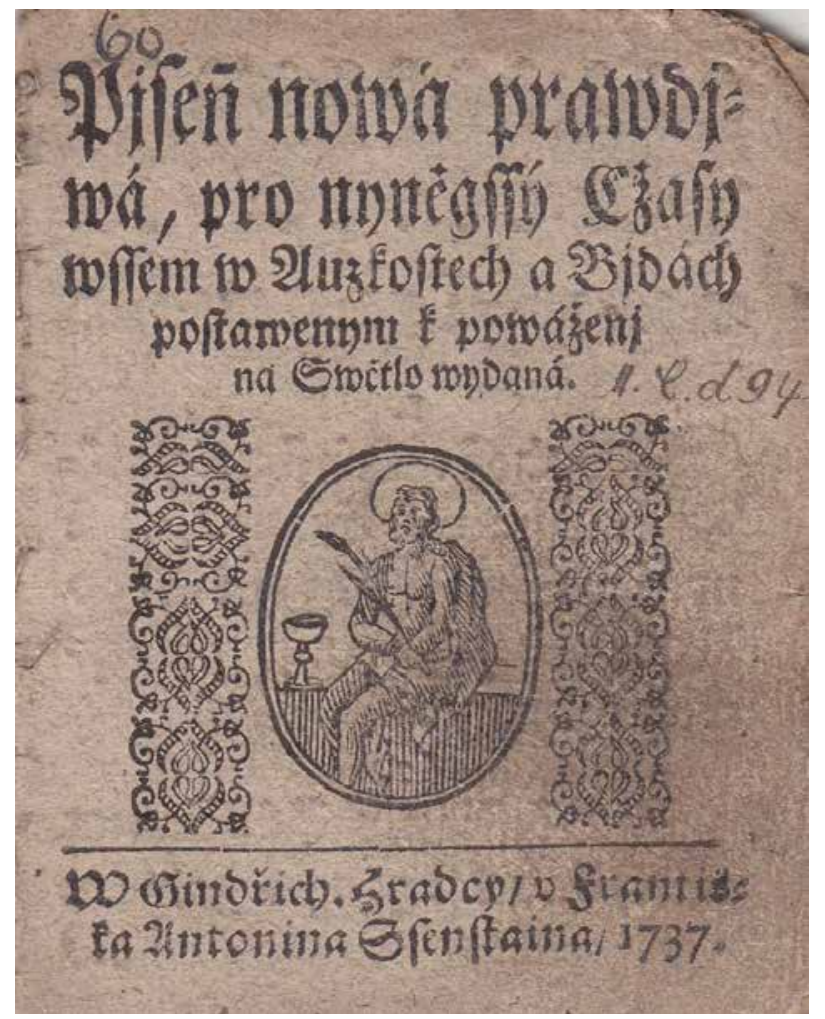

Obr. 6. Píseň nová pravdivá, pro nynější časy všem v ouzkostech a bídách postaveným k povážení na světlo vydaná. J. Hradec, František Antonín Schönstein, 1737. 8 s., $102 \times 80$ mm. Nápěv: Adam Pán Bůh stvořil. Incipit. Ej pobožní křestané, patřme na vše strany. Sbírka MJH, K 3558.

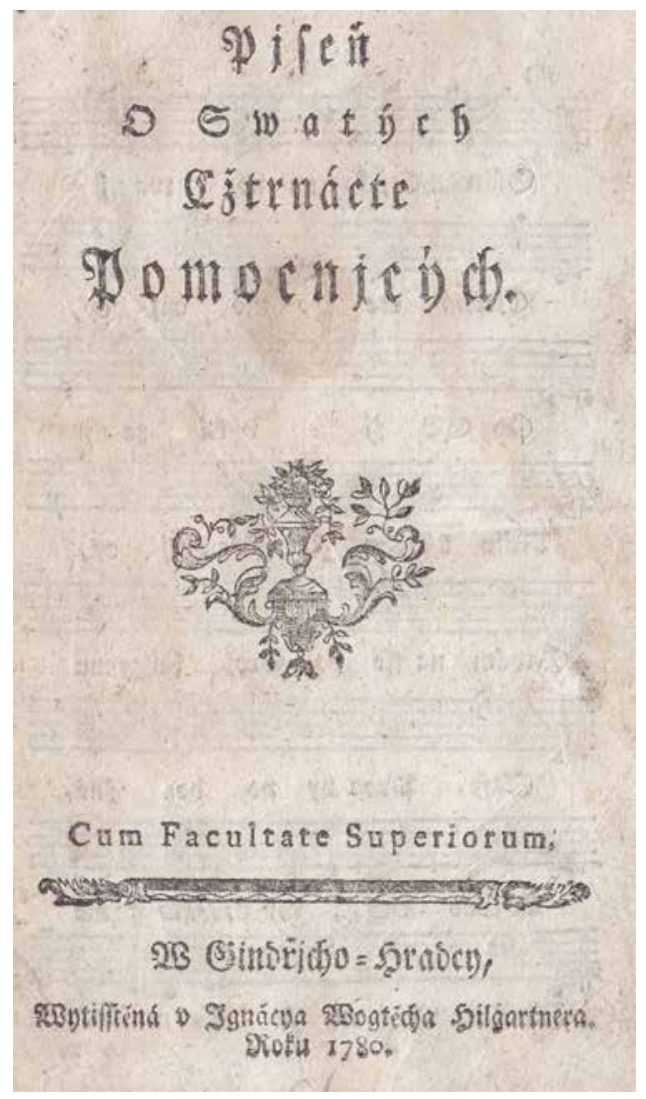

Obr. 8. Píseň o svatých čtrnácte pomocnících. J. Hradec, Ignác Vojtěch Hilgartner, 1780.4 s., $185 \times 115$ mm. Incipit: Slávou, ctí korunovaní. Sbírka MJH, K 6454. 


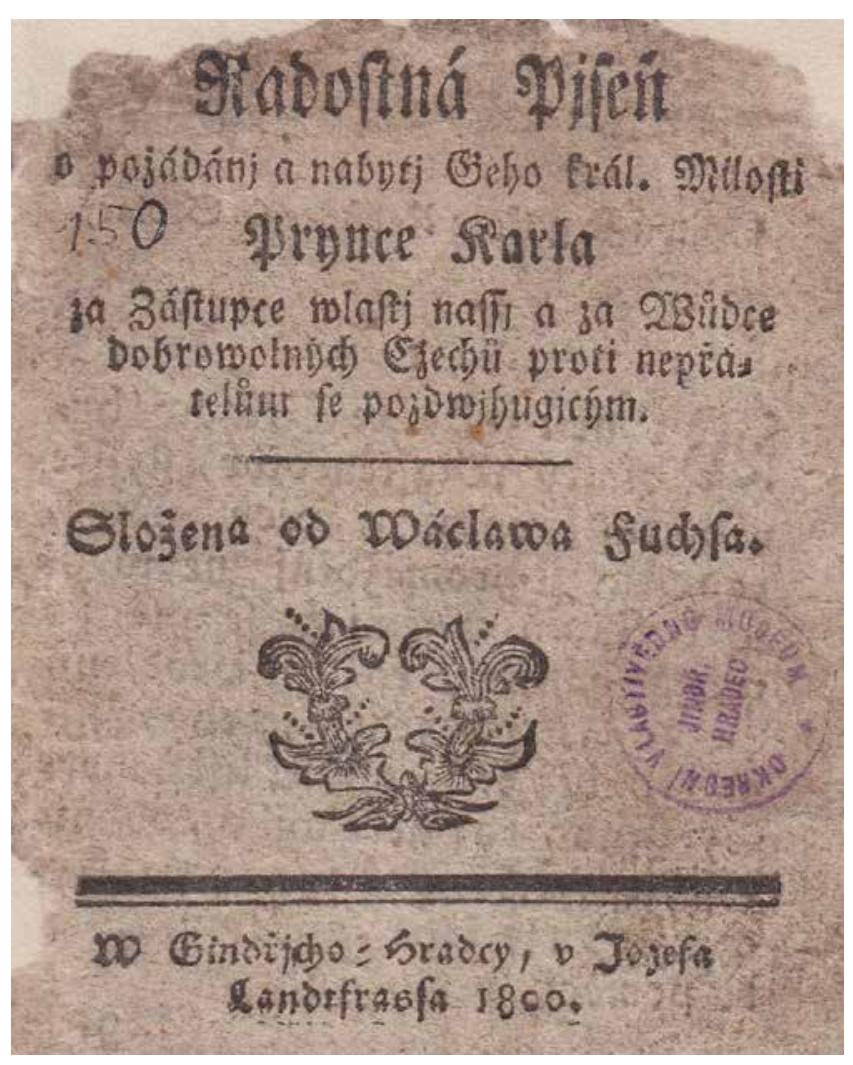

Obr. 9. Fuchs, Václav, Radostná píseň po požádání a nabytí jeho král. Milosti prince Karla za zástupce vlasti naší... J. Hradec, Josef Landfras, 1800.8 s., $110 \times 88 \mathrm{~mm}$. Incipit: Vzhůru vstaňte Čechové. Sbírka MJH, K 3115

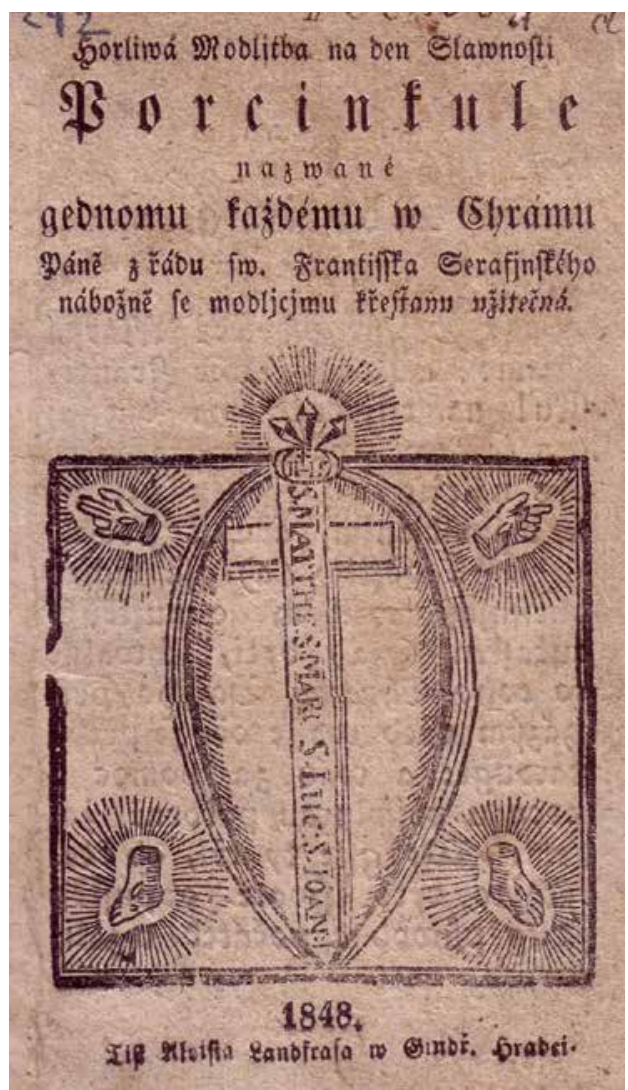

Obr. 11. Horlivá modlitba na den slavnosti Porcinkule nazvané. J. Hradec, Alois Landfras, 1847. 12 s., $144 \times 86$ mm. Incipit: Pane Ježíši Kriste! Maria Panno! Sbírka MJH, K 3823.

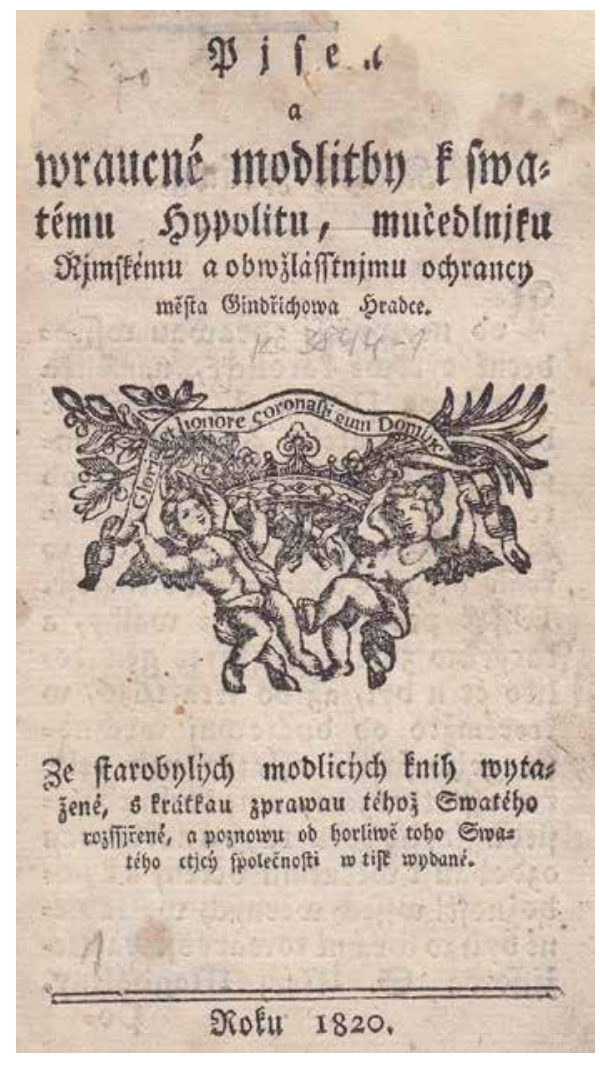

Obr. 10. Píseň a vroucné modlitby $\mathrm{k}$ svatému Hipollytu, ... ochránci Jindřichova Hradce. J. Hradec [Josef Landfras], 1820. 8 s., $150 \times 92$ mm. Incipit: Ej, prozpěvovat míníme. Nápěv: Pochválen bud'Pán Bůh náš. Sbírka MJH, K 3844.

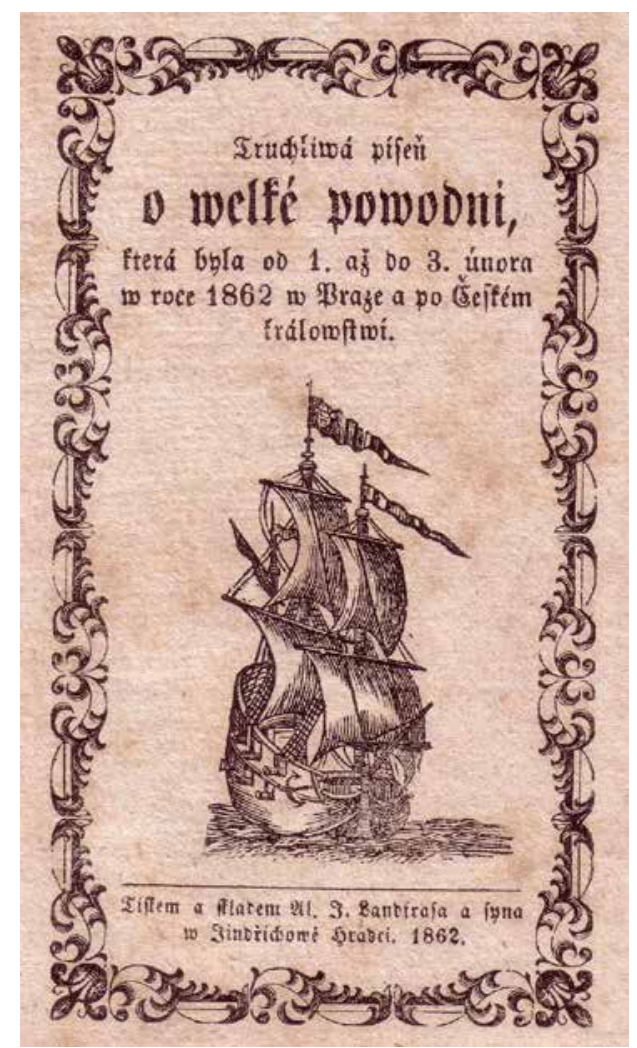

Obr. 12. Truchlivá píseň o velké povodni, která byla od 1. až do 3. února v roce 1862 v Praze a po Českém království. J. Hradec, A. J. Landfras a syn, 1862.8 s., $148 \times 92$ mm. Incipit: Ach proboha drazí krajané. Sbírka MJH, K 5838. 


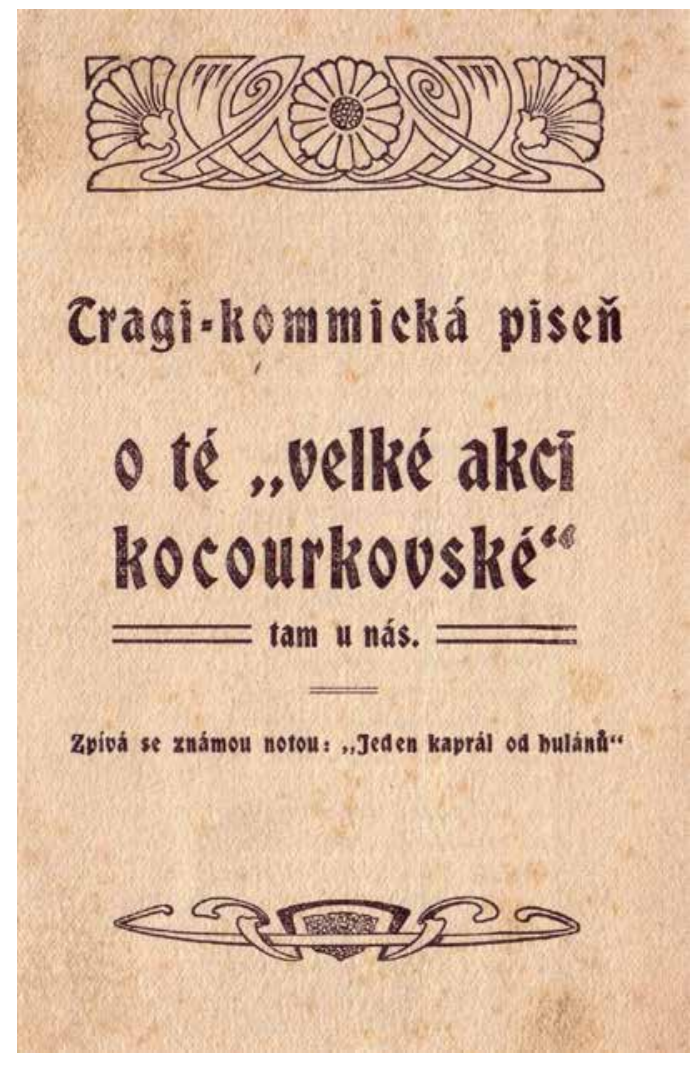

Obr. 13. Tragikomická píseň o té veliké akci koucourkovské tam u nás. [J. Hradec, A. Landfras Syn, po roce 1900?]. 6 s., $182 \times$ $98 \mathrm{~mm}$. Incipit: Poslyšte občané milí. Nápěv: Jeden kaprál od hulánů. Sbírka MJH, K 4597.

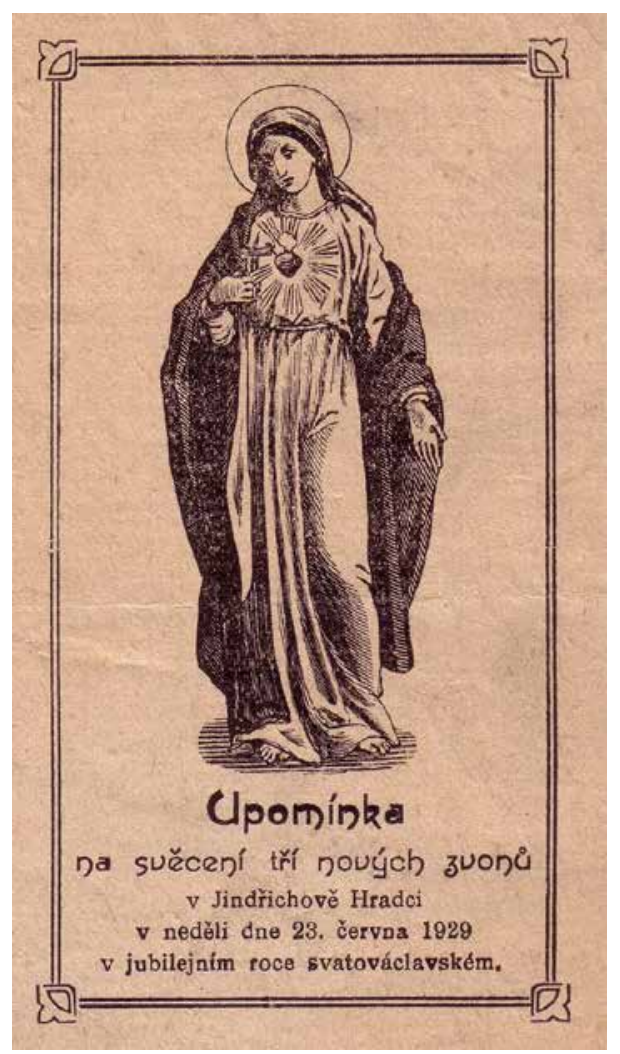

Obr. 15. Upomínka na svěcení tří nových zvonů v Jindřichově Hradci v neděli dne 23. června 1929. J. Hradec, A. Landfras Syn, 1929. 4 s., $131 \times 79 \mathrm{~mm}$. Incipit: Necht' zazní pane jasným zvukem. Sbírka MJH, K 4593.

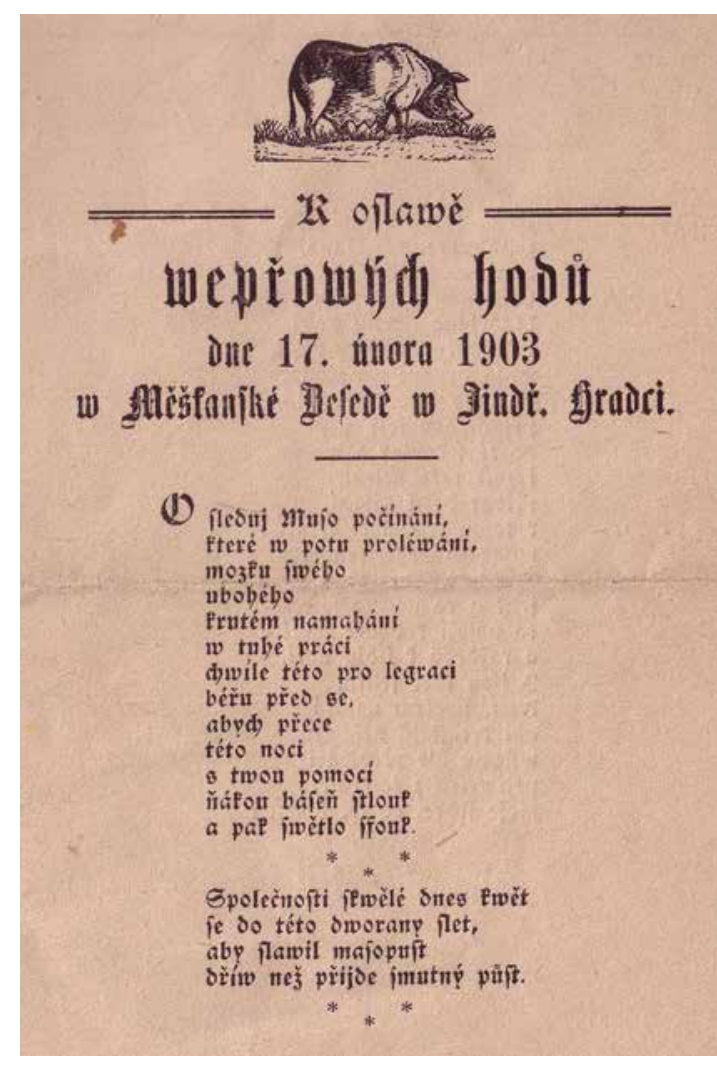

Obr. 14. Tejčka, Matěj, K oslavě vepřových hodů dne 17. února 1903 v Měštanské besedě v Jindř. Hradci. J. Hradec, A. Landfras Syn, 1903.4 s., $177 \times 112$ mm. Incipit: O, sleduj múzo počínání. Sbírka MJH, K 4604.

\section{Piseñ k sv. Janu Nepomuckému.}

1.

Kam jdeš, Jene, kam pospícháš, že se s námi žehnáš, ku Praze tak smutně kráčíš, vale nám zde dáváš; snad se více nenavrătíš, a nás zde opustit míníš, ach, neopust́ sv. Jene, za to tě žádáme.

\section{2.}

Budiž vůle mého Boha, bud tvá, o Maria! nebot́ vím, že mne přivítá, ukrutnost Václava; požádá pouti ode mně, tu musím dáti ve Vltavě, bude chtít, zvěděti na mnẽ zpověd’ o krălovně.

\section{3.}

Dobře se měj, na to nedbej, že se s tebou loučím, v lásce Boží vždy

Obr. 16. Píseň k sv. Janu Nepomuckému. [J. Hradec, tiskárna Alexandr, 1944]. 4 s., $149 \times 93$ mm. Incipit: Kam jdeš Jene, kam pospícháš. Sbírka MJH, K 3398. 


\section{ZÁSVËTNÁ MODLITBA}

\section{K PANNĚ MARII}

POMOCNICIKŘESTAANU்,

PROSTŔEDNICI VŚECH MILOSTI

幽

\begin{abstract}
Milosti plná Matko Boži Maria, I plni posvátné radosti $\mid$ přistupujeme dnes před Tvůj trůn | ke cti nejsvětějši Trojice | a našeho Pána a Spasitele Ježí̌e Krista.

Před veškerým dvorem nebeským | zasvěcujeme se Ti | a $s$ dětinnou důvěrou | stavíme se pod Tvou zvláštni záštitu. | Ty bư' naši mocnou a dobrotivou ochrán. kyní! | Chraň naši diecési | našeho
\end{abstract}

Obr. 17. Zásvětná modlitba k Panně Marii, pomocnici křest’anů, prostřednici všech milostí. Olomouc, Lidové závody, 1940. 4 s., $122 \times 78$ mm. Incipit: Milostiplná Matko Boží Maria. Sbírka MJH, K 4967.

z pražské tiskařské dílny J. Michala Sama z roku $1789^{37}$ a poté byl používán v Landfrasově tiskárně v Jindřichově Hradci.

Jiná analýza kramářských tisků byla zaměřena na Pannu Marii Svatohorskou, ${ }^{38}$ přičemž bylo dohledáno 14 originálů štočků z celkem 49 různých otisků nacházejících se na 108 kramářských tiscích $\mathrm{s}$ touto tematikou $\mathrm{z}$ období od druhé poloviny 18. století až po konec století devatenáctého. $\mathrm{V}$ řadě př́padů je znázorněna ikonograficky soška Panny Marie Svatohorské, někdy i s poutním místem, jiné použil tiskař nahodile a jedná se většinou o obecnou mariánskou tematiku - tedy vyobrazení Panny Marie a výjevů z jejího života. Naopak vyobrazení Panny Marie Svatohorské byla užívána i na obecných mariánských tiscích bez přímého vztahu ke Svaté Hoře. Např. jeden z nejstarších štočků souboru znázorňuje Pannu Marii Svatohorskou stojící na kopci nad stavbou se třemi věžemi v rokokovém rámečku a jeho otisk se nachází na pražském tisku z dílny Karla Samma

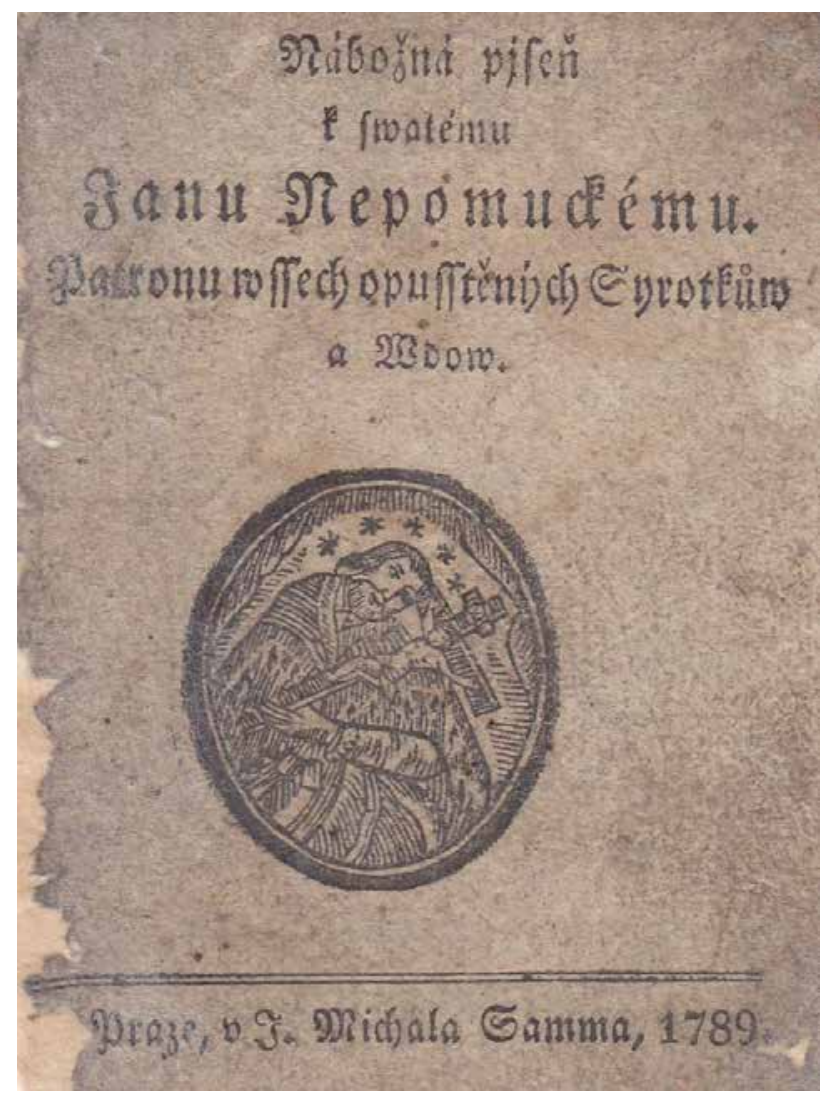

Obr. 18. Nábožná píseň k svatému Janu Nepomuckému. Praha, J. Michal Samm, 1789. 6 s. doch., $115 \times 88$ mm. Incipit: Nejsem zavázán žádnému. Sbírka MJH, K 5289.

z roku $1786 .{ }^{39}$ Totožný štoček je otištěn i na Nábožné písni k Panně Marii Svatohorské z Uherské Skalice z přelomu 18. a 19. století, v 19. století jej nabízeli Landfrasové zákazníkům tiskárny v dochovaném ukázkovém albu štočků. ${ }^{40}$ Dále bylo nalezeno několik párů velice podobných štočků a jejich otisků, zhotovených úmyslně jako kopie. Některé $\mathrm{z}$ nich byly užívány pouze $\mathrm{v}$ jindřichohradecké tiskárně. ${ }^{41}$ Zajímavý je pár dochovaných štočků, které znázorňují kněze s procesím u sochy Panny Marie s Ježíškem. ${ }^{42}$ Jeden z nich byl užíván v tiskárně Jana Spurného v Praze ${ }^{43}$ kolem poloviny 19. století, a jeho otisk je doložen na pěti pražských tiscích, druhý je otištěn na celkem 20 tiscích z Landfrasovy tiskárny v Jindřichově Hradci datovaných od poloviny až do 80 . let 19. století. Nejstarší tisky jsou z období A. J. Landfrase, jeden je datován do roku 1857 , další byly tištěny v období 1858-1864, kdy pracovala firma pod názvem A. J. Landfras a syn. Z nich je přesněji do roku 1859 datována Horlivá píseň $k$ Panně Marii z pera známého písničkáře Františka

\footnotetext{
${ }^{37}$ Jan Michal Samm působil jako tiskař a nakladatel v letech 1756-1787. VOIT 2006. Jan Michal Samm [online], c2018, [Cit. 1. 7. 2021] <https:// www.encyklopedieknihy.cz/index.php?title $=$ Jan_Michal_Samm\&oldid $=14336>$

${ }^{38}$ BĚHALOVA 1994, s. 22-23.

${ }^{39}$ Viz poznámku č. 15. Podle Voita náležel do rodiny Jana Michala Samma také tiskař kramářských písní Karel (František) Samm. Jeho pražská dílna je nesoustavně doložena v letech 1774, 1786-1789 a 1797-1798.

${ }^{40}$ Album s otisky štočků z Landfrasovy tiskárny. J. Hradec: A. J. Landfras, pol. 19. století. Dostupné z: https://kramerius.mjh.cz/uuid/ uuid:d4537340-fe03-11df-bf27-000d606f5dc6

${ }^{41}$ BĚHALOVÁ 1994, s. 46-47.

${ }^{42}$ BĚHALOVÁ 1996.

${ }^{43}$ VOIT 2006, Jan Spurný [online], c2019, [Cit. 1.7.2021] <https://www.encyklopedieknihy.cz/index.php?title=Jan_Spurn\%C3\%BD\&oldid=16656>
} 


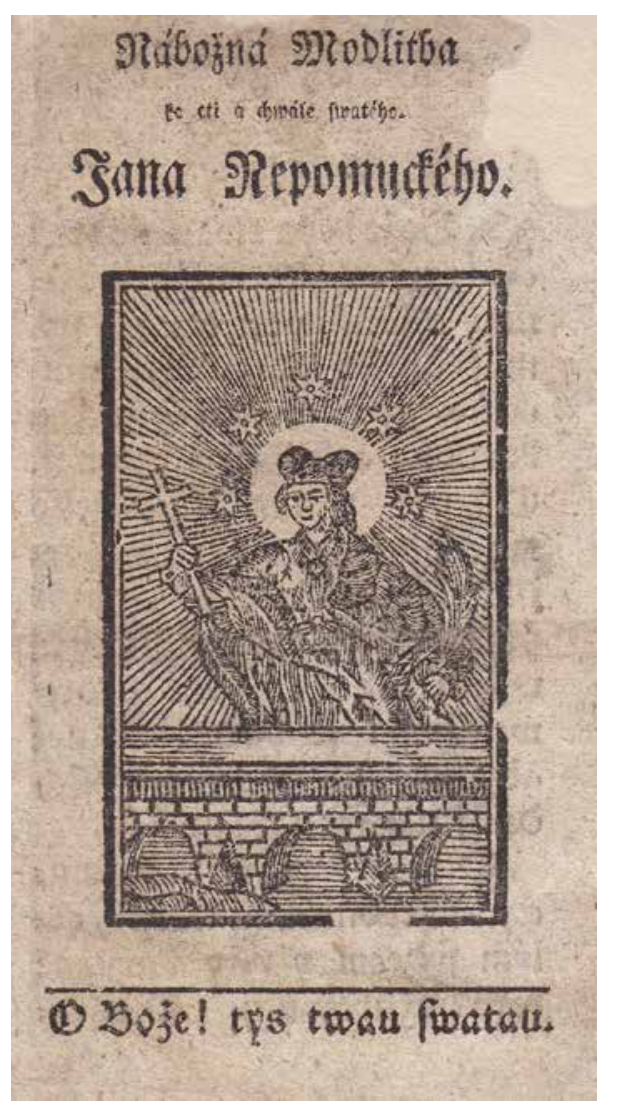

Obr. 19. Nábožná modlitba ke cti a chvále svatého Jana Nepomuckého. [S. I., s. n., před 1810]. 4 s., $167 \times 110$ mm. Incipit: O bože, tys svou svatou církev. Sbírka MJH, K 4244.

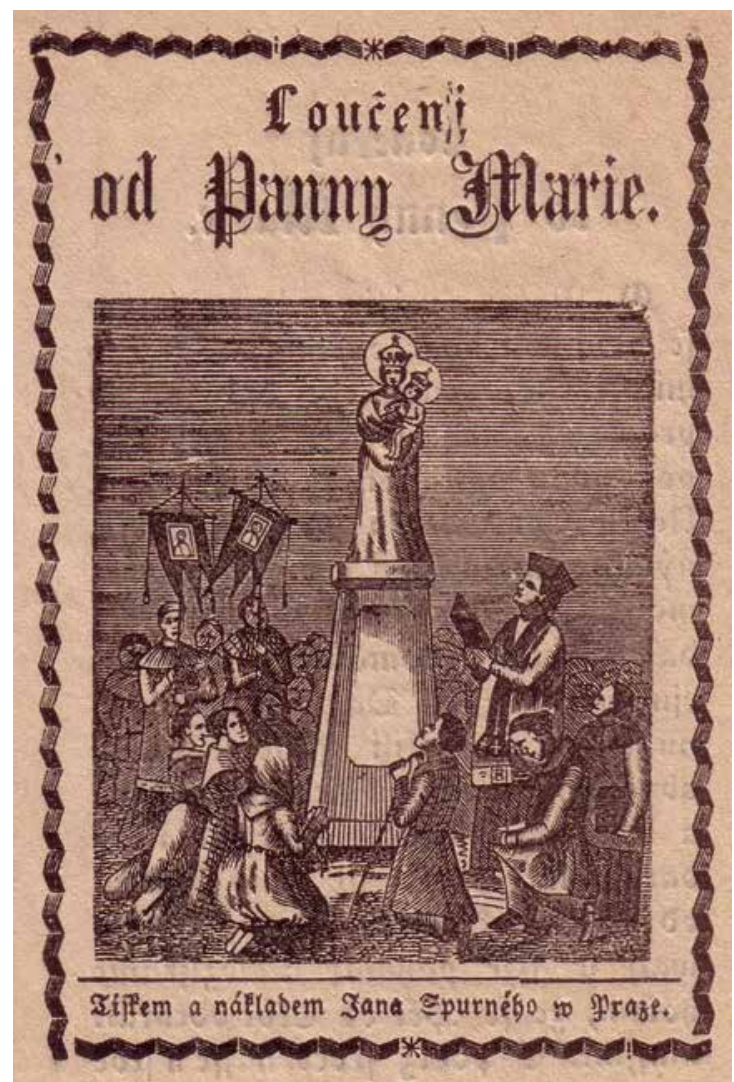

Obr. 21. Loučení od Panny Marie. Praha, J. Spurný, [před 1860?]. 4 s., $154 \times 78 \mathrm{~mm}$. Incipit: O Maria, máti Milostná. Sbírka MJH, K 3682 .

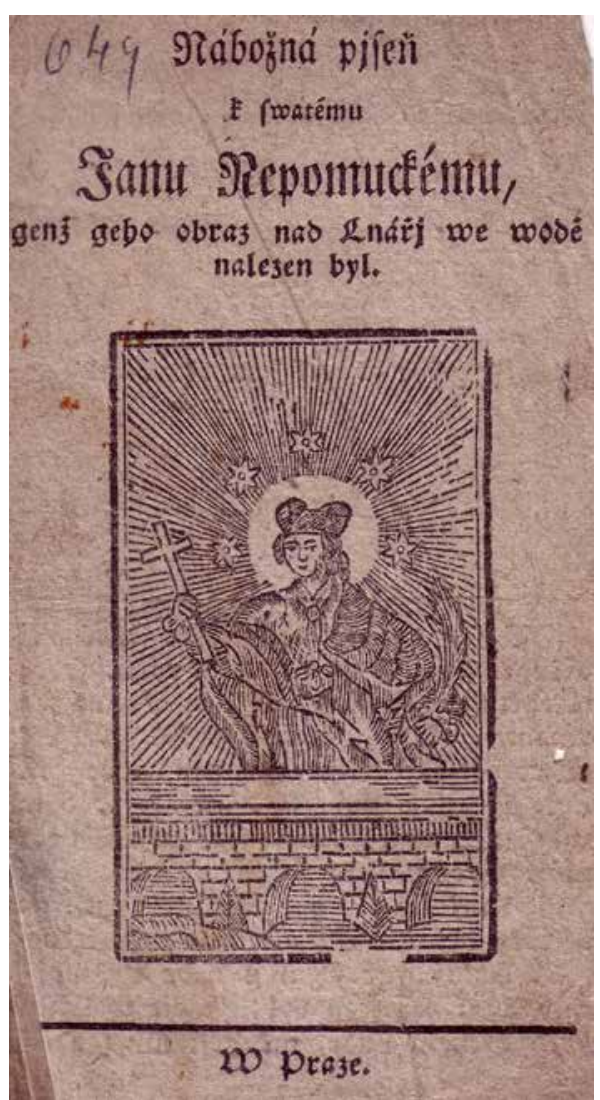

Obr. 20. Nábožná píseň k svatému Janu Nepomuckému. [S. I., s. n., po 1810]. 4 s., $155 \times 90 \mathrm{~mm}$. Incipit: Bože, z tvé svaté milosti. Nápěv: Svatý Jene Nepomucký. Sbírka MJH, K 4982.

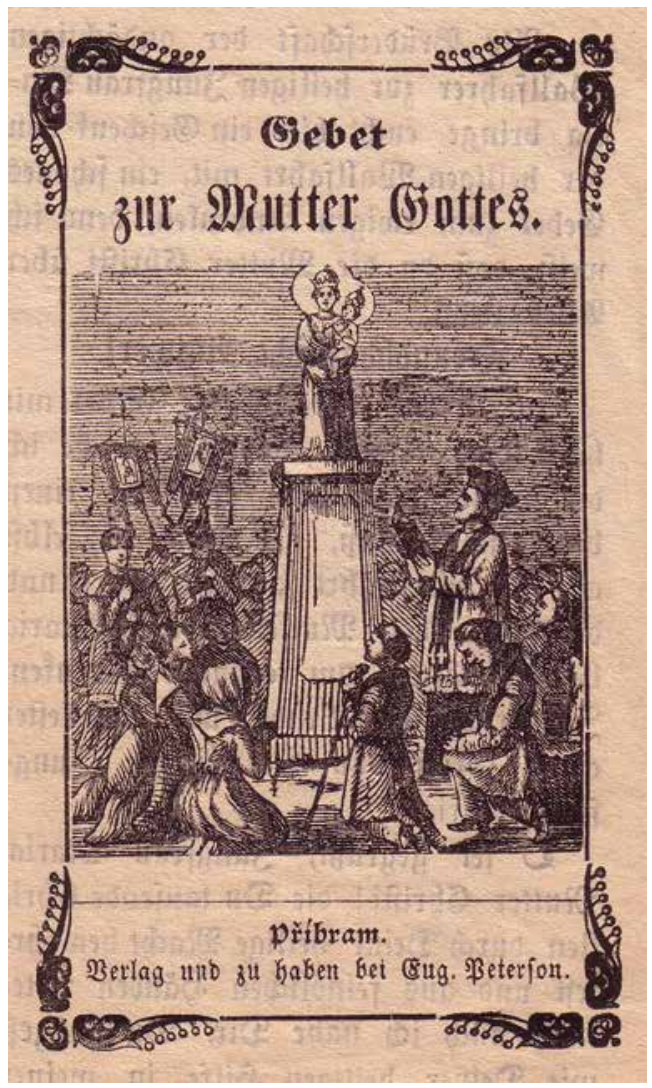

Obr. 22. Gebet zur Mutter Gottes. Príbram, E. Peterson, [po 1864]. Druck von Al. Landfras Sohn. 4 s., $147 \times 87 \mathrm{~mm}$. Incipit: Als Brüderschaft der andächtigen Wallfahrer. Sbírka MJH, K 4468. 
Haise. ${ }^{44}$ Zbývající tisky jsou z tiskárny A. J. Landfras Syn z období po roce 1864. Zatímco tiskař Jan Spurný vydal všechny tisky vlastním nákladem, některé tisky z jindřichohradecké Landfrasovy tiskárny mají jiného nakladatele, jako tomu bylo například v př́ípadě Haisovy písně, jejímž nakladatelem byl autor, a dalších 14 tisků bylo tištěno u firmy A. J. Landfras syn pro př́bramského nakladatele Eugena Petersona (činný 1858-1905), ${ }^{45}$ který svou nakladatelskou produkci směroval na poutníky a návštěvníky příbramské Svaté Hory, a to především prostřednictvím českých a německých modliteb a písní tištěných formou kramářského tisku. Nabídku doplňoval světskými písněmi. Zajímavé je, že tisk pro něj zajišt'ovala převážně jindřichohradecká tiskárna A. Landfras syn, v menší míře i pražská firma Jan Spurný a její nástupce tiskárna Jul. Janů. $V$ názvech tisků převažuje Loučeni od Panny Marie, někdy s upřesňujícím Svatohorské s incipitem O Maria, máti milostná! nebo Předrahá matko, královno nebes a Pochválen bud' Pán Ježiš Kristus. Dále se mezi tisky objevuje píseň Na tisíckráte pozdravuju tebe a modlitba s incipitem Hlubokou ponižeností a s velkou vroucností. Několik tisků je doplněno nakladatelským seznamem knih Landfrasovy tiskárny. K odlišení vzhledu titulní strany byly užity jednoduché nebo z tiskařských znamének a ozdůbek sestavené rámečky. Dále je patrné snížení kvality otisku štočku a postupné zmenšení rozměru otisku vzniklé jeho opakovaným použitím a opotřebením. ${ }^{46}$

I když byly v 18. století kramářské tisky obvykle vydavatelským a nakladatelským počinem tiskárny, která nejčastěji vznik těchto tisků sama financovala a také zařizovala odbyt, v 19. století vzniklo i v tomto odvětví odlišné ekonomické prostředí, v němž se tiskárně podařilo značně zvýšit podíl zakázek oproti vlastním nakladatelským a vydavatelským aktivitám. U poutních kramářských tisků 19. století z jindřichohradecké Landfrasovy tiskárny je v 50 \% uvedeno jméno nakladatele. Většinu z těchto tisků objednal výše zmíněný příbramský obchodník, nakladatel Eugen Peterson. Je zde patrný i větší podíl tisků, u nichž je uvedeno jméno osoby odpovědné za text, mnohdy s přesným určením podílu na autorství textu. Místo náboženského bratrstva, typického organizátora poutí $\mathrm{v}$ předchozích staletích, které bylo v některých př́ípadech i nakladatelem tištěné písně či modlitby, získali v 19. století svou pozici vedoucí náboženských procesí a zpěváci. Kramářský tisk tak byl jedním ze zpo̊sobů jejich přivýdělku, a proto jej nejen prodávali, ale často sami texty skládali a nechali si náklad vytisknout. Díky svému kontaktu s poutníky a jejich dokonalé znalosti pak $\mathrm{v}$ textech cílili na jejich projevy víry spojené s emocemi a hraničící s pověrčivostí.

Počtem ve zkoumaném souboru vynikají písně profesionálního vưdce poutních procesí Františka Haise, pro něhož tiskla jindřichohradecká Landfrasova tiskárna na přelomu 50. a 60. let 19. století.

$\mathrm{Z}$ jazykového hlediska je ve fondu zastoupena ve více než $80 \%$ čeština, necelých $20 \%$ tisků je v němčině. Početně největší soubory kramářských tisků $\mathrm{v}$ němčině pocházejí z Jindřichova Hradce a Prahy. Podíl němčiny v jindřichohradecké Landfrasově tiskárně v 19 . století činil přibližně $12 \%$ tisků. V tomto období býval v tiskárně tištěn tentýž text $\mathrm{s}$ totožným obrázkem $\mathrm{v}$ češtině i v němčině, případně byl užit jiný název i jiný text, ale totožná podoba titulního listu, jako je tomu např́klad v Loučení od Panny Marie (obr. 21) a v německém tisku Gebet zur Mutter Gottes (obr. 22) tištěném u Landfrase pro príbramského nakladatele Eugena Petersona.

Tisky byly členěny podle zaměření textu na náboženské a světské. Světská témata jsou v analyzovaném souboru doložena pouze u $12 \%$ celého souboru, zbývajících $88 \%$ se řadí do náboženské tematiky. Dosud uváděné údaje registrovaly obvykle pouze kramářskou píseň a uváděly poměr $75 \%$ náboženských a $25 \%$ světských písní, ${ }^{47}$ případně poměr světských témat na jednu třetinu ku dvěma třetinám náboženských. ${ }^{48}$ Průzkum fondu KT MJH zahrnul písňové i nepísňové texty v kramářských tiscích. Při formálním zkoumání fondu podle názvů tisků se objevují slova písen̆, písnička, písně, písničky v $75 \%$ tisků, zbývající čtvrtina, a to především náboženských kramářských tisků, obsahuje v názvu nejčastěji slovo modlitba, modlitby, dále se objevuje loučení, pobožnost, památka, žalář, uctění, vzývání a upomínka. Zvýšení poměru náboženských témat ve fondu Muzea Jindřichohradecka je proto možné vysvětlit několika skutečnostmi. Posun pravděpodobně souvisí s tím, že průzkum byl proveden v celé oblasti kramářských tisků, nikoliv jen v kramářských písních, s nimiž pracovali autoři výše uvedených procentuálních zastoupení. Dalším faktorem, který pravděpodobně zvýšil počet náboženských kramářských tisků, je silné zastoupení tisků z 19. století, a to v souvislosti s převažující produkcí náboženské a modlitební literatury v jindřichohradecké Landfrasově tiskárně. ${ }^{49}$ S tímto zaměřením tiskárny pak souvisely kontakty s autory, knihkupectvími a dalšími prodejci.

Téměř $40 \%$ všech písňových i nepísňových náboženských kramářských tisků je věnováno Panně Marii, cca 15 \% Ježíši Kristovi, kolem 8 \% sv. Janu Nepomuckému a sv. Anně, menší procento pak dalším světcům (sv. Alois, Cyril a Metoděj, Josef, Florián, František, Ivan, Jiří, Václav, Vojtěch, jindřichohradečtí patroni Hippolyt a Theodor) a světicím (sv. Anna, sv. Alžběta, sv. Barbora, sv. Kateřina a další). ${ }^{50}$

Tradiční katolická zbožnost byla pevnou součástí tehdejšího života především venkovských obyvatel. Kromě

\footnotetext{
${ }^{44}$ HAIS 1985.

${ }^{45}$ V Muzeu Jindřichohradecka se dochovaly dva dopisy Eugena Petersona firmě A. Landfras Syn do J. Hradce z roku 1867 týkající se tisku objednaných děl (Sbírka MJH, Knižní kultura, KK 556, 557), doplňuje je i v dopisech zmiňovaný rukopis: Jan Nepomuk Jentsch, Svatá Hora, poutni misto v Čechách, Sbírka MJH, fond Rukopisy, Rk 451. ZACH 2008, Eugen Peterson [online]. [Cit. 1. 7. 2021] Dostupné z: https://www. slovnik-nakladatelstvi.cz/nakladatelstvi/eugen-peterson.html

${ }^{46}$ BĚHALOVÁ 1996b.

${ }^{47}$ BENEŠ 1970, 1998.

${ }^{48}$ BYDŽOVSKÁ 2010

${ }^{49}$ BĚHALOVÁ 2017b.

${ }^{50}$ BĚHALOVÁ 2013.
} 


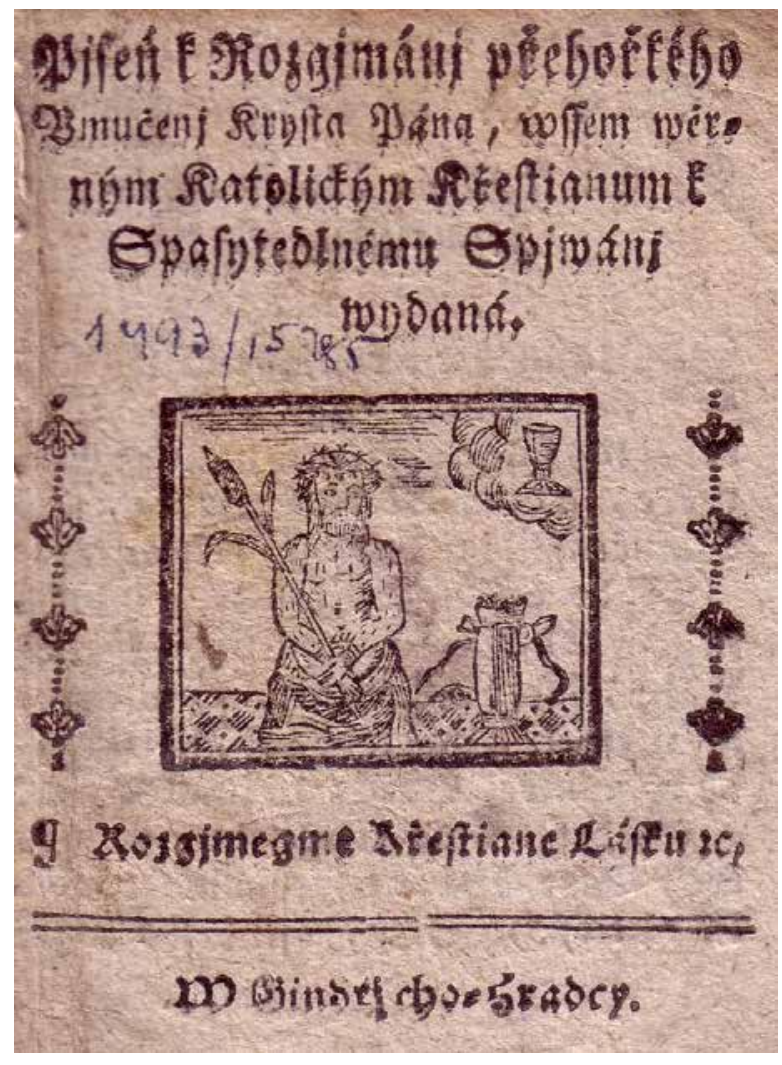

Obr. 23. Píseň k rozjímání přehořkého umučení Krista Pána. Jindřichův Hradec, s. n., [přelom 18. a 19. století]. 6 s. doch., $110 \times 90$ mm. Incipit: Rozjímejte křest’ané Lásku Krista. Nápěv: Pozdraven bud' Františku. Sbírka MJH, K 2821.

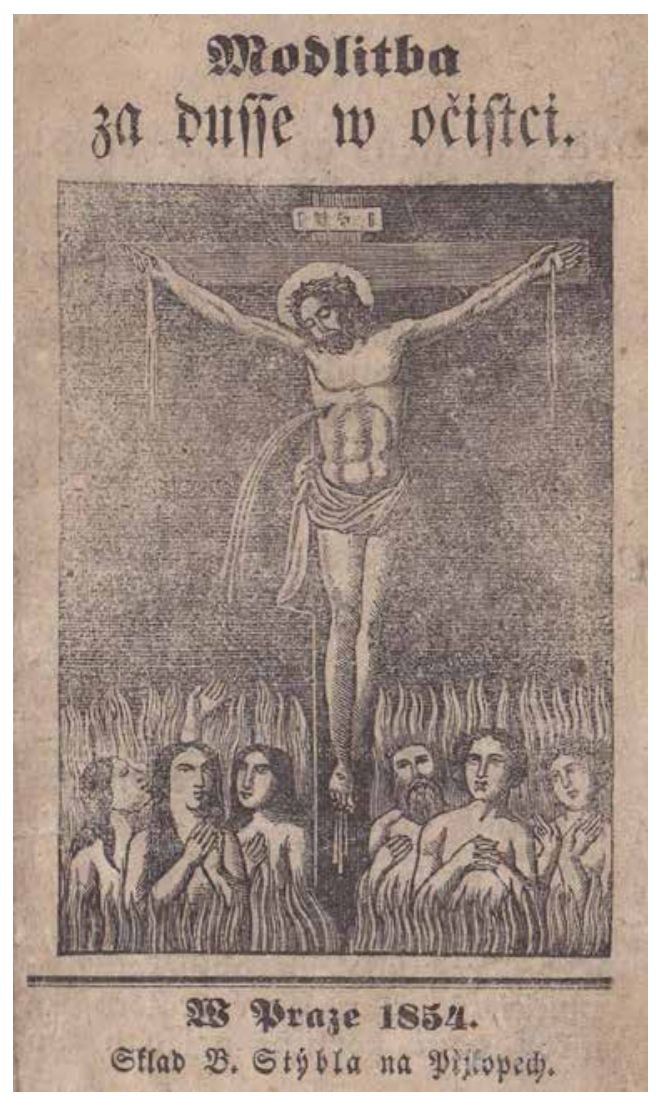

Obr. 25. Modlitba za duše v očistci. Praha, B. Stýblo 1854. Tisk K. V. Medau. 4 s., $137 \times 82 \mathrm{~mm}$. Incipit: Otče náš, jenž jsi na nebesích. Sbírka MJH, K 5249.

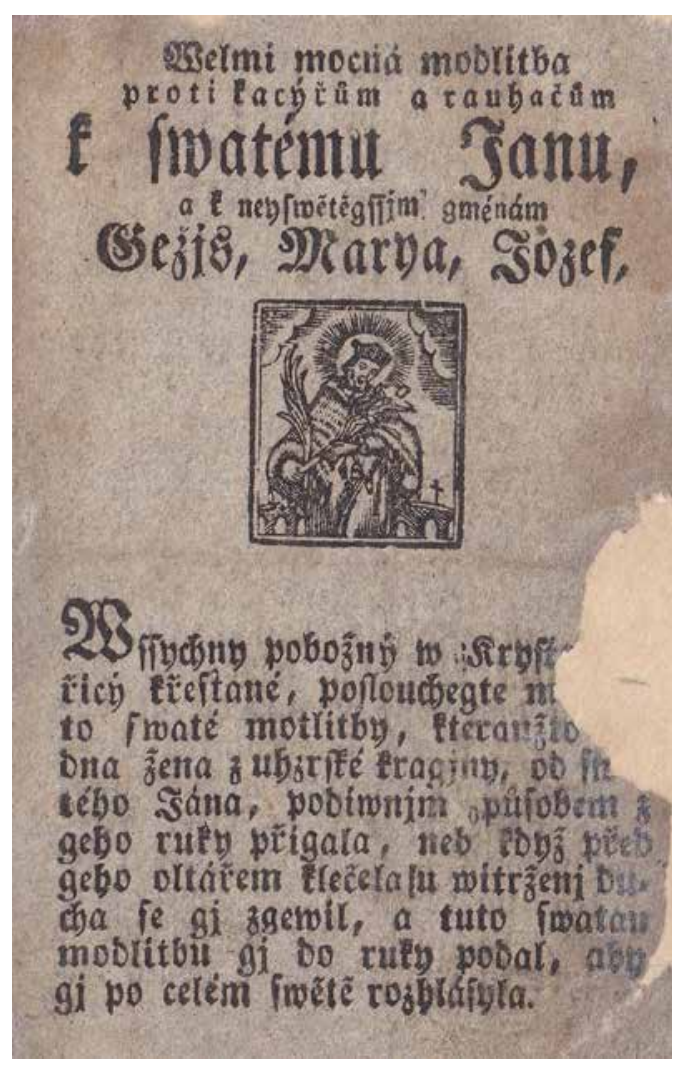

Obr. 24. Velmi mocná modlitba proti kacírưm a rouhačům k svatému Janu, a k nejsvětějším jménám Ježíš, Maria, Josef. [S. I., s. n., přelom 18. a 19. století]. 4 s., $148 \times 92 \mathrm{~mm}$. Incipit: Všichni pobožní v Kristu věřící křest’ané poslouchejte. Sbírka MJH, K 4751.

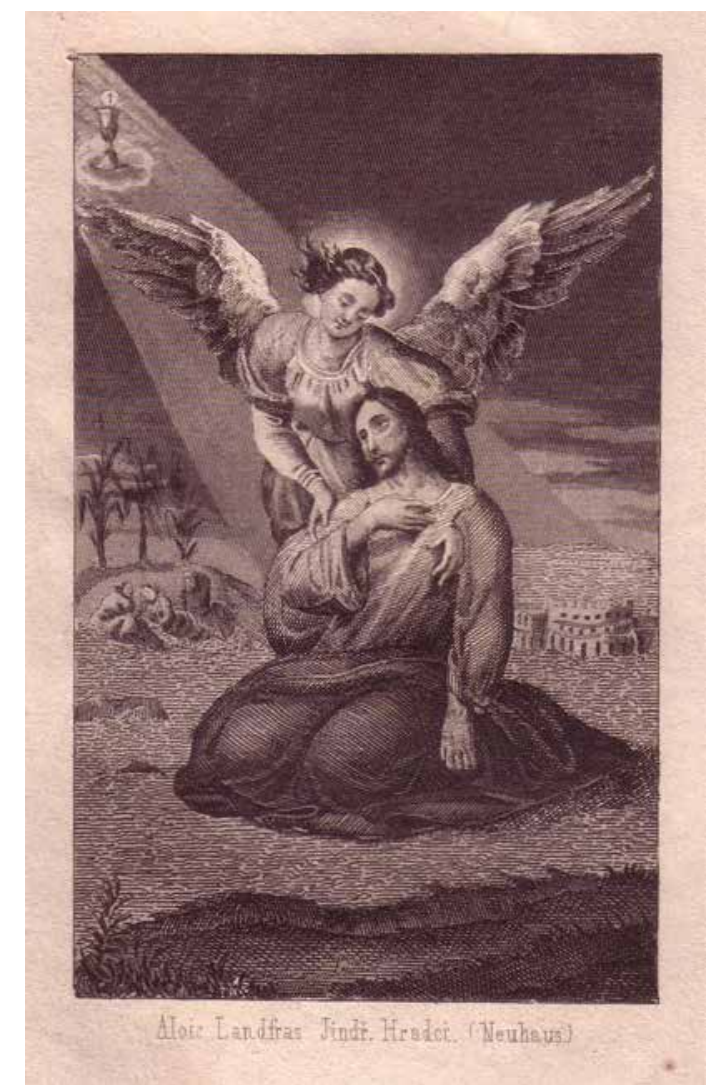

Obr. 26. Ježíšova svatá hodinka na hoře Olivetské. J. Hradec, A. J. Landfras 1854.6 s., $129 \times 84$ mm. Incipit: Pán Ježíš, maje vykonati veliké dílo vykoupení. Sbírka MJH, K 5859. 


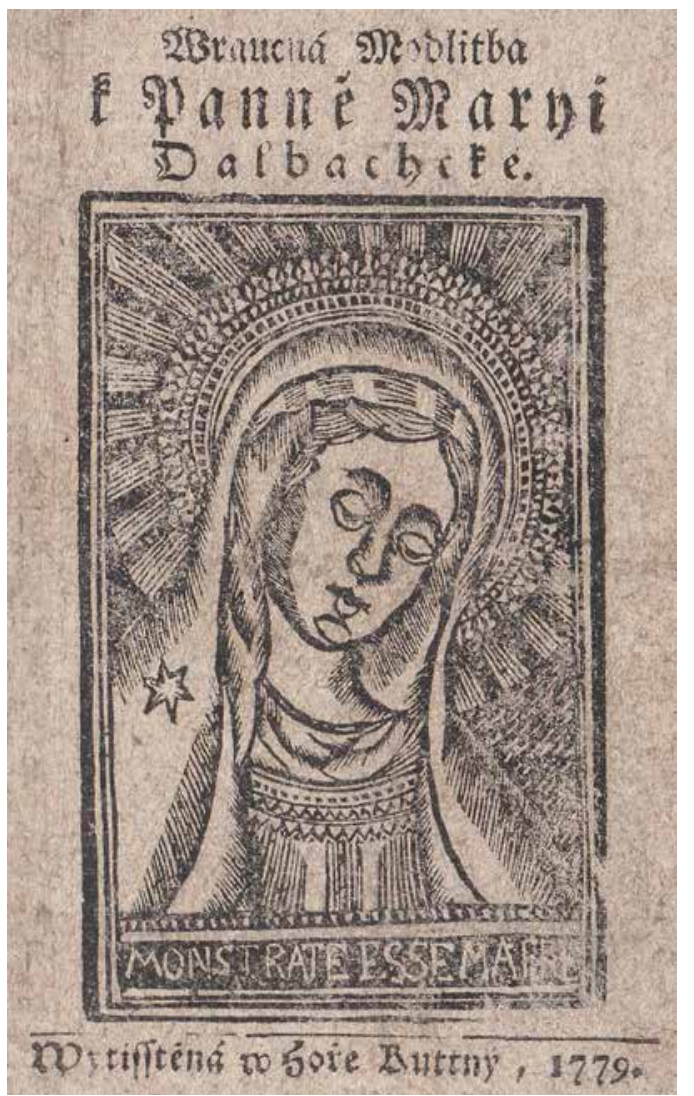

Obr. 27. Vroucná modlitba k Panně Marii Dalbachské. Kutná Hora, s. n., 1779.4 s., $135 \times 80$ mm. Incipit: Bud' pozdravená mnoho milionu tisíckrát slávy hodná. Sbírka MJH, K 4924.

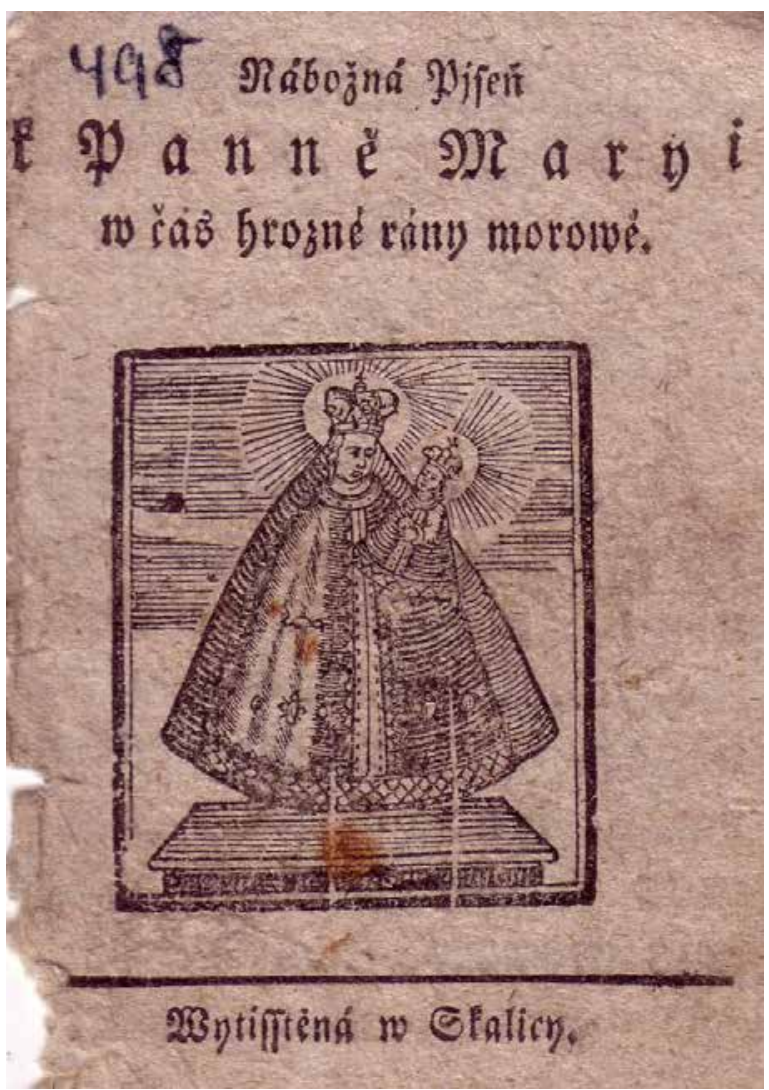

Obr. 29. Nábožná píseň k Panně Marii v čas hrozné rány morové. Skalica, s. n. [kolem 1830?]. 8 s., $120 \times 90$ mm. Incipit: Pod tvůj plášt’ se utíkáme. Sbírka MJH, K 5150.

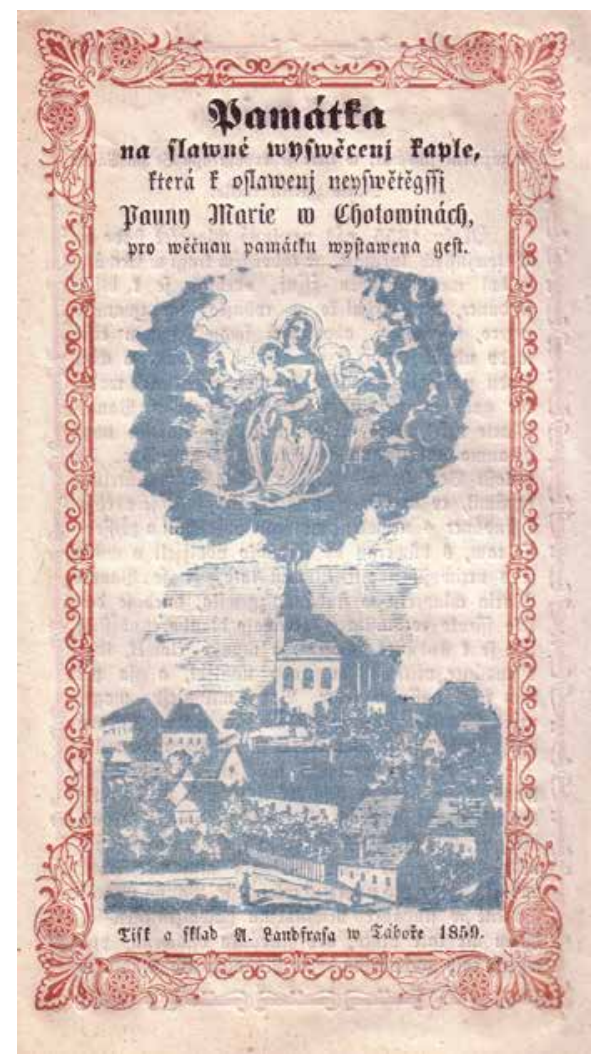

Obr. 28. Památka na slavné vysvěcení kaple, která k oslavení nejsvětější Panny Marie v Chotovinách pro věčnou památku vystavěna jest. Tábor, A. J. Landfras, 1859. 4 s., $178 \times 110$ mm. Incipit: Historie o zázračné studánce. Sbírka MJH, K 5872.

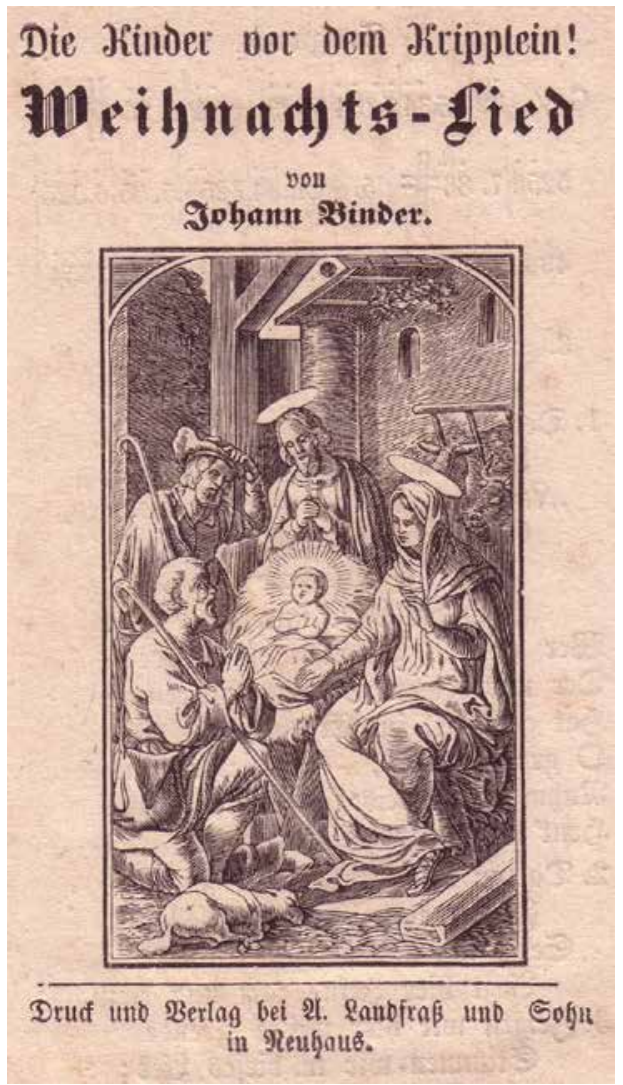

Obr. 30. Binder, Johann, Die Kinder vor dem Kripplein! J. Hradec, A. J. Landfras syn, 1868.4 s., $152 \times 95 \mathrm{~mm}$. Incipit: Der die Menschheit angenommen. Sbírka MJH, K 5726. 
osobní modlitby, pravidelné účasti na mši, úcty ke svatým jako ochráncům domácnosti, rodiny, dětí, opuštěných sirotků a vdov a umírajících, k ní patřila náboženská pout'. Značné množství kramářských tisků s náboženskou poutí úzce souvisí, především proto, že byla vhodným místem $\mathrm{k}$ jejich distribuci, a kramářský tisk byl také levným skladným upomínkovým předmětem, památkou nebo dárkem z cesty. Ve fondu KT MJH se objevují tisky související s poutními místy z jindřichohradecké i mimohradecké produkce. Zastoupením dominují tradiční a známá poutní místa, kam pravidelně docházela procesí či jednotliví poutníci z celých Čech a Moravy (např. Lurdy, Mariazell, Vambeřice, Svatá Hora, Stará Boleslav, Křtiny, Svatý Kopeček, Štípa). Další skupinu tvoří větší poutní místa $\mathrm{v}$ jižních Čechách (Bechyně, Chlum, Římov, Nová Včelnice, Kostelní Vydří) a místa menší, s významem spíše místním, jako jsou např. Drahov, Chotoviny a Mláka. ${ }^{51}$ Vzhledem k velkému podílu tisků z jindřichohradeckých tiskáren jsou přirozeně početně více zastoupena místa, kam směřovala procesí z Jindřichova Hradce. Ve výčtu poutních míst je patrný také odraz obchodních kontaktů, které především v 19. století rozvíjela Landfrasova tiskárna, přičemž největší akcent je patrný od druhé poloviny 19. století na Svatou Horu, především díky př́ibramskému nakladateli Eugenu Petersonovi, který tiskl u Landfrasů.

Prostřednictvím kramářských tisků je možné sledovat potřeby přicházejících věřících a sled rituálů konaných při pouti k určitému místu, nebo dokonce posloupnost vzniku poutní tradice $\mathrm{v}$ konkrétní lokalitě. Zatímco soubor tisků věnovaných tradičnímu baroknímu poutnímu místu Svatá Hora u Př́brami zahrnuje tisky z 18. i 19. století, tisky věnované nově vzniklému poutnímu místu v Chotovinách u Tábora pocházejí až z poloviny 19. století, kdy se poutní místo utvářelo. ${ }^{52}$ Svatohorské kramářské tisky tak představují vývoj podoby titulního listu v průběhu téměř 150 let, chotovinské tisky, ač zachovávají některé tradiční prvky podoby kramářského tisku (rozměry, rozsah, sazba, vizualizační a evidenční aparát, dekor, ilustrace, jednotný titulní list), obsahují různorodé texty (píseň, modlitba, vinš, památka, loučení) a navíc využívají nové tiskařské techniky v oblasti výzdoby, zejména litografii. Kramářské tisky se zde staly propagátory a sehrály význam při rozšíření legendy o zázračné chotovinské studánce.

Samostatný oddíl tvoři prosebné a děkovné modlitby a písně, především za úrodný déšt' a za odvrácení nemoci a moru, následované poděkováním za splnění proseb a přímluvami $\mathrm{k}$ andělu strážci. Na kramářských tiscích se objevily v 19. století také památky na růžencovou slavnost, texty určené ke mši svaté či ke konkrétní významné festivitě církevního roku, nejčastěji k adventu nebo Vánocům..$^{53}$

Moralizující charakter typický pro texty kramářských tisků je nejvíce patrný u textů s tematikou konce života, smrti a posmrtného života. Jedná se o texty o posledních věcech člověka a věčné odplatě pracujících, mementa mori i konkrétní písně určené ke zpěvu s umírajícím, písně pohřební a památky na zesnulé. Některým typům textů byl přikládán zázračný účinek ve prospěch toho, kdo je uvedeným způsobem předříkával. Přestože je církev odmítala, či dokonce zakazovala, zázračná formulka bývala na kramár̆ském tisku často uvedena. Ještě ve 3 . čtvrtině 19 . století tak lze na tisku objednaném u Landfrase př́ibramským nakladatelem Eugenem Petersonem číst i pověrečnou formuli: ,, Kdo tuto modlitbu nábožně se modlí, toho Matička Krista Ježíše nikdy neopustí, ale vždy za něj u syna svého orodovat bude a odpuštění hř́chů mu vyprosí. " Peterson si u Landfrase objednal také tisk Sedmi svatých a nebeských zámků. Tato modlitba, kterou dostal zbožný poustevník od svého strážného anděla, měla pomáhat od všech škodlivých vlivů. ${ }^{54}$

Kramářské tisky se světskými i náboženskými náměty jsou obecně určeny pro prŕíjemce $\mathrm{z}$ venkova i z města, $v$ př́ipadě jindřichohradeckých tiskáren, podobně jako u jiných mimopražských tiskáren, je zřetelná orientace na venkovské př́jemce. U světských kramářských tisků převažují události obyčejného všedního života od narození, dospívání přes dospělost až k smrti. Kromě pozornosti věnované především tématům lásky a manželského života (včetně nešvarů souvisejících například s holdováním alkoholu, nevěrou apod.) líćí i mnohé zábavné události týkající se rodinného života. Nechyběly ani texty popisující společenské novinky, některé vypjaté situace, kriminální činy a katastrofy. ${ }^{55}$ Jejich podíl ve fondu KT z MJH je poměrně nízký a díky vysokému zastoupení produkce 19. století i hlavní orientaci tiskárny a nakladatelství na modlitební literaturu ustupuje převažujícím lyrickým textům, akcentovaným $\mathrm{v}$ písních „pro mládence a panny“ s širokým spektrem textů od lidové písně až k soudobému společenskému zpěvu. Zajímavým dokladem těsně souvisejícím s obsahem kramářských písní je zpěvník vydaný u Aloise Landfrasa v roce 1845 pod názvem Sbirka 118te světských písní k obveseleni vlastenské mládeži. Písně ze zpěvníku se objevují na kramářských tiscích z Landfrasovy tiskárny i z dalších tiskáren. Ve zpěvníku jsou řazeny podle incipitu, jejich rozborem a porovnáním s Pichlovým Společenským zpěvníkem českým z roku 1851 se zabývala podrobně Eva Ryšavá, ${ }^{56}$ která se věnovala též problematice působení kramářských skladeb na autory básní v Zieglerově Dobroslavu a jejich pozdějším otiskům. ${ }^{57}$ Koncem 19. století v souvislosti s rozvojem kupletů a satiry se objevují na tiscích s vnějším vzhledem kramářského tisku výjimečně i texty odrážející život středních vrstev maloměsta a žertovné texty neformálních maloměstských společenských skupin.

V oblasti náboženské kramářské písně je pro 19. století zajímavá např. mešní píseň Boleslava Jablonského

\footnotetext{
${ }^{51}$ BĚHALOVÁ 1994, 1995, 1996a, 1997.

52 BĚHALOVÁ 2006.

${ }^{53}$ BĚHALOVÁ 2019.

${ }^{54}$ VEČERKOVÁ 1998.

${ }^{55}$ PÍSKOVÁ 2002.

${ }^{56}$ RYŠAVÁ 1998.

${ }^{57}$ RYŠAVÁ 1997.
} 


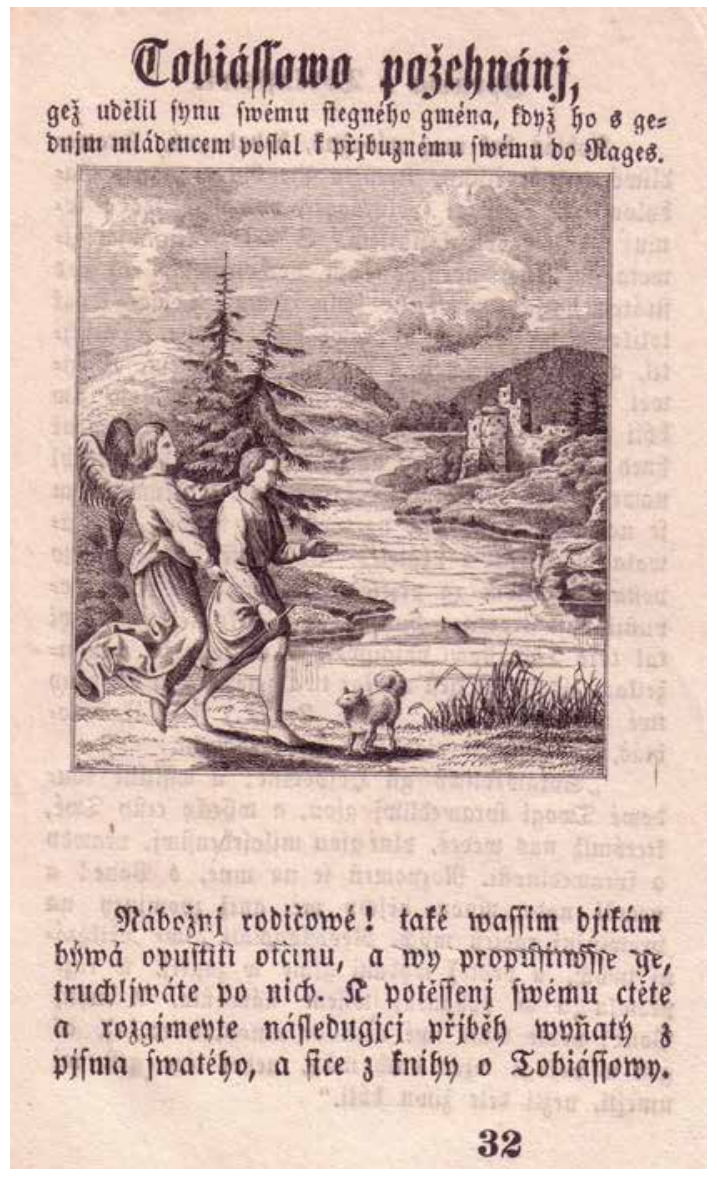

Obr. 31. Tobiášovo požehnání. J. Hradec, A. J. Landfras, 1854. 4 s., $129 \times 84$ mm. Incipit: Nábožní rodičové, také vašim dítkám... Sbírka MJH, K 5829.

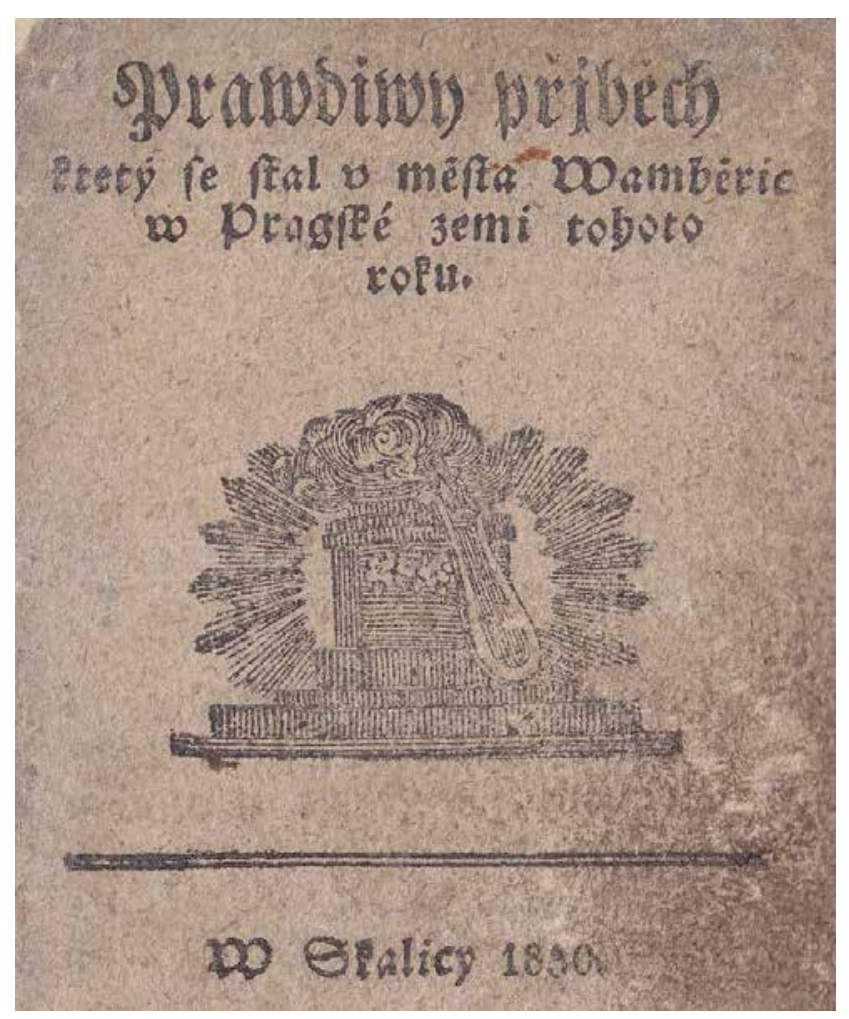

Obr. 33. Pravdivý příběh, který se stal u města Vambeřic v Prajské zemi. Skalica, s. n., 1800.8 s., $104 \times 82$ mm. Incipit: Poslechněte krajanové tu nynější novinu. Sbírka MJH, K 4609.

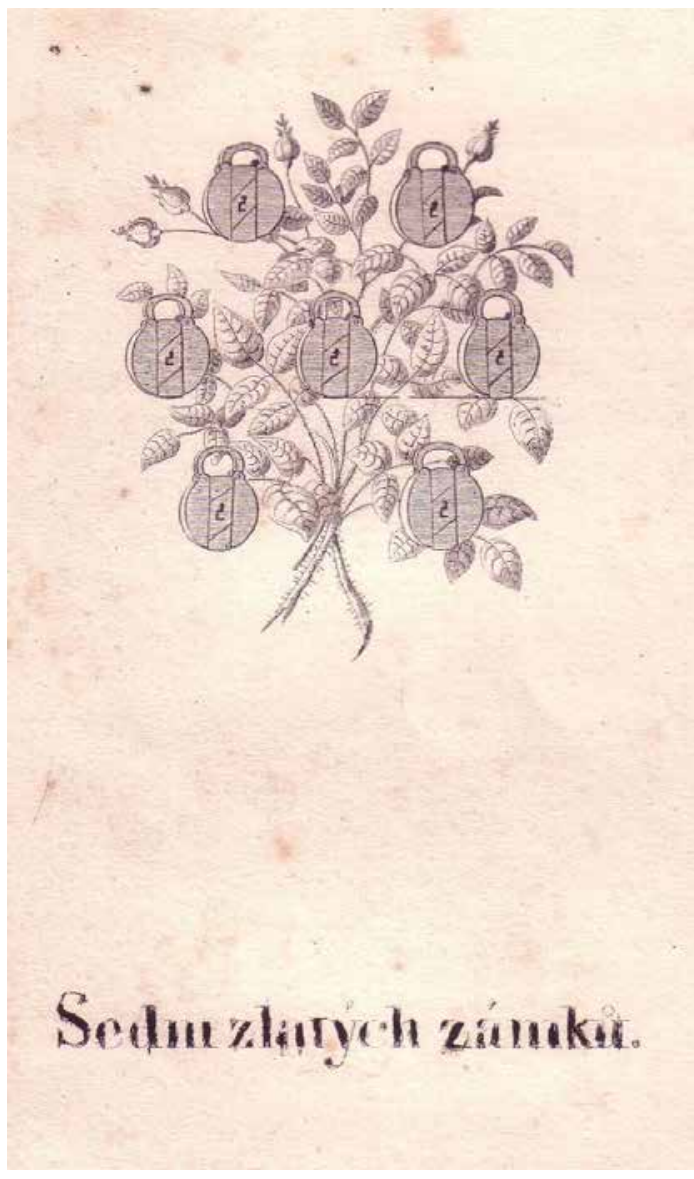

Obr. 32. Sedm zlatých zámků. J. Hradec, A. J. Landfras, 1854. 6 s., $134 \times 87 \mathrm{~mm}$. Incipit: Jakož ve dne poctivě chod'me. Sbírka MJH K 5664 .

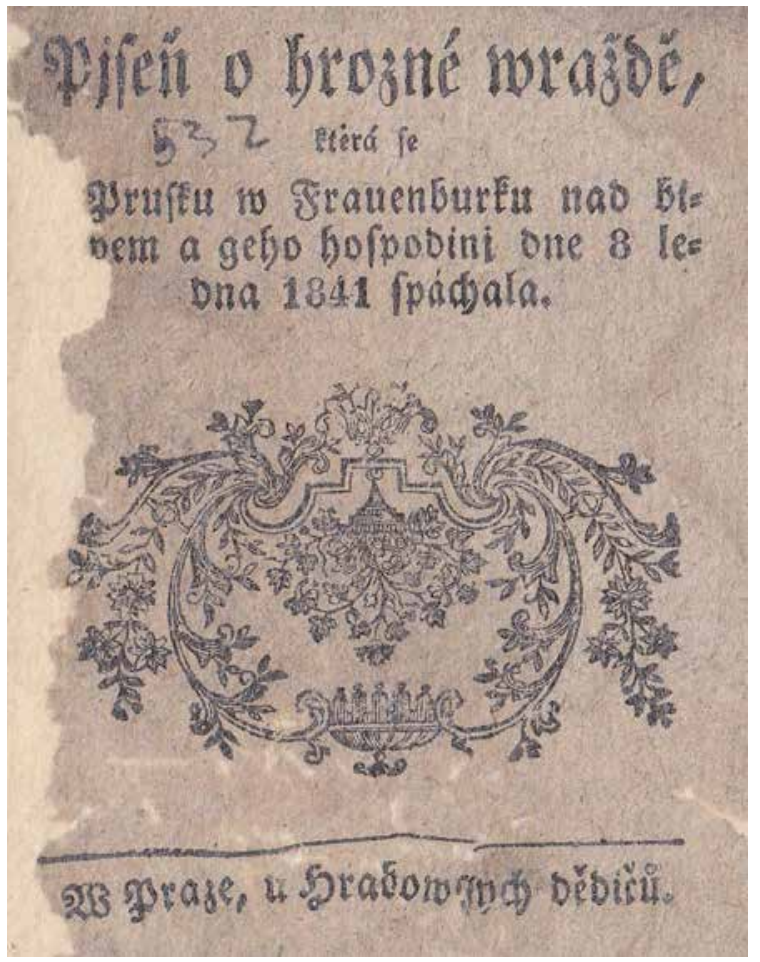

Obr. 34. Píseň o hrozné vraždě, která se v Prusku u Frauenburku nad biskupem a jeho hospodyní dne 8. ledna 1841 spáchala. Praha, u Hrabovských dědiců, po 1841.16 s., $167 \times 115 \mathrm{~mm}$. Sbírka MJH, K 5226. 


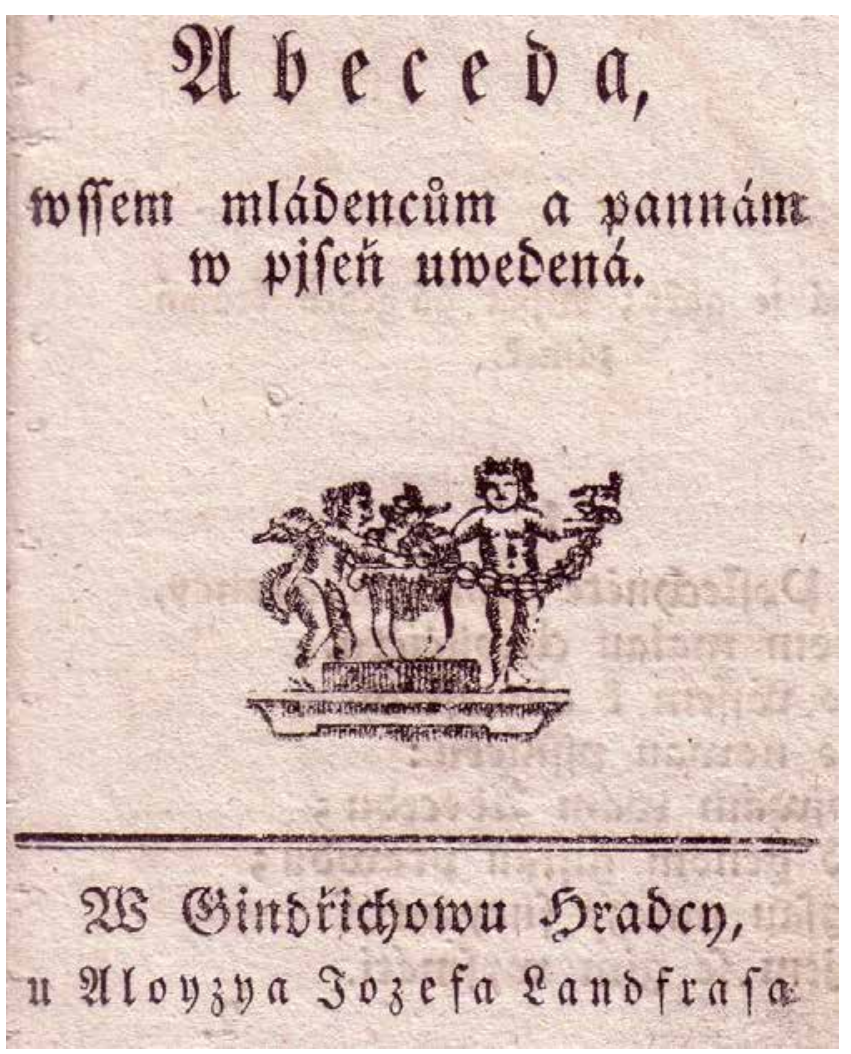

Obr. 35. Abeceda, všem mládencům a pannám v píseň uvedená. J. Hradec, A. J. Landfras [po 1826?]. 8 s., $105 \times 98$ mm. Incipit: Poslechněte mě mládenci. Nápěv: Vímt’ já jeden krásný zámek. Sbírka MJH K 3095.

Pozdvihni se duše z prachu, ${ }^{58}$ která je dnes součástí jednotného kancionálu (oddíl ordinária a obecné mešní písně č. 517). Tato píseň byla publikována $\mathrm{v}$ několika typech tištěných médií, přičemž nejstarší vydání je doloženo právě ve formě kramářského tisku z roku 1845 a následující minimálně z let 1849 a 1850, 1854, 1855 a 1859 . V roce 1852 ji autor textu osobně zařadil do druhého vydání modlitební knihy Růže sionská a byla otištěna $\mathrm{v}$ dalších zpěvnících druhé poloviny 19. století. Prolínání publikování textu písně uznávaného básníka a literáta $\mathrm{z}$ kramářských tisků do zpěvníků a modlitebních knih je zajímavým a řídkým dokladem cesty umělé písně do jednotného kancionálu. Pro předchozí století doložil prolínání textů písní z kancionálu do kramářských tisků a naopak např́klad Jan Malura v úvodu jeho edice Jana Josefa Božana Slaviček rájský. ${ }^{59}$

Závěrem je nutno uvést, že pro zkoumaný fond Kramářské tisky z Muzea Jindřihohradecka je typická převažující produkce Landfrasovy tiskárny s akcentem na 19. století, hlavní období působení a rozkvětu Landfrasovy tiskárny. Kramářský tisk zařadila do své produkce stejně jako další typické tiskařké produkty. Studium fondu kramářských tisků z Muzea Jindřichohradecka přineslo nové závěry, které posunují dosud publikované teze vzešlé z výzkumu kramářských tisků ze 17. a 18. století. Týká se to především vyššího počtu kramářských tisků s náboženskou tematikou, vyššího

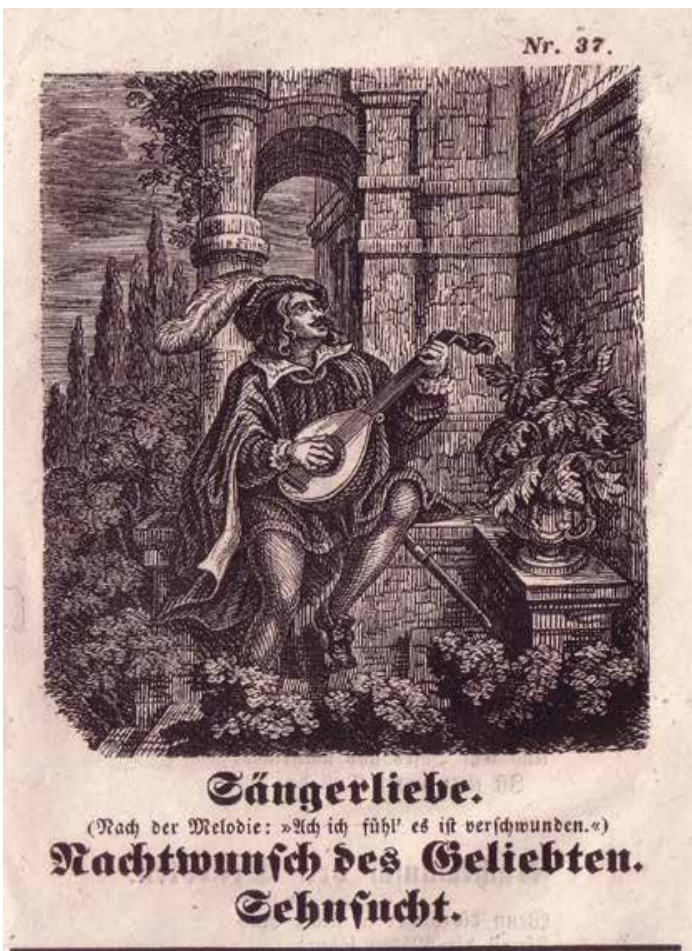

TBien, bei S. Buemant, Folograph; savoritenftraßce, Shaumburgergruno $\Re r$. 78, 1. Etod̆, ₹hür $\Re r .11$.

Obr. 36. Sängerliebe. Wien, S. Buemann, [před 1848]. 4 s., $186 \times$ 122 mm. Incipit:Wenn die Nacht in stiller Ruh. Sbírka MJH, K 5138.

počtu nepísňových textů v kramářských tiscích nebo změn ve formální podobě kramářské písně, která je nejvíce patrná v oblasti výzdoby a údajů na titulním listu. Kolem poloviny 19. století stoupá počet datovaných kramářských tisků, do oblasti produkce kramářských tisků se promítají nové nakladatelské vztahy a také se objevují častěji jména osob odpovědných za vznik tisku, at' se jedná o autory, překladatele nebo upravovatele textu.

Díky tomu, že Landfrasové ve vlastním vydavatelském profilu akcentovali náboženskou a modlitební literaturu především pro venkovské obyvatelstvo, soustředili do této oblasti také produkci kramářských tisků. Kolem tiskárny vznikal postupně okruh dalších nakladatelů podobně zaměřených titulů, kteří zde práci zadávali. V dochovaném souboru náboženských kramářských tisků 19. století zvláště vyniká soubor nepísňových kramářských tisků a také soubor kramářských písňových a nepísňových tisků souvisejících s náboženskou poutí 19. století. Díky tomu je možné sledovat proměny vnější podoby kramářských tisků v 18. a 19. století, použití rozdílných technik výzdoby, počínaje dřevořezem přes ocelorytinu, dřevoryt až $\mathrm{k}$ litografii, ale také odlišných přístupů $\mathrm{k}$ jejich zhotovení. Zatímco nejstarší dřevořezy se mezi tiskárnami i vyměňovaly, v 19. století byly často zhotoveny zcela analogické dřevoryty. $\mathrm{V}$ některých případech je užívaly různé tiskárny, $v$ dalších jen jedna, a to jak z důvodu opotřebení prvního štočku, tak pravděpodobně i k urychlení práce při tisku

\footnotetext{
${ }_{58}^{58}$ BĚHALOVÁ 2017.

${ }^{59}$ MALURA 1999.
} 


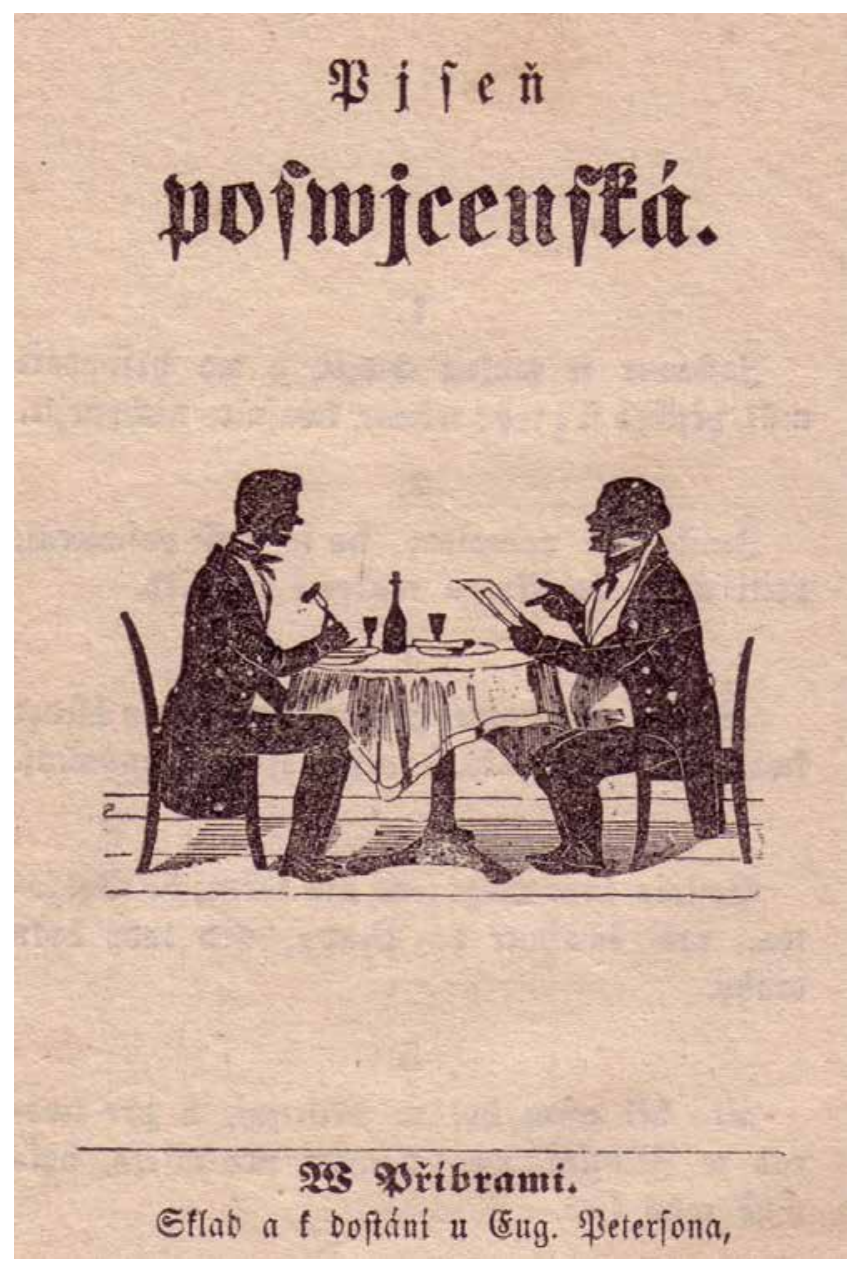

Obr. 37. Píseň posvícenská. Př́bram, E. Peterson [po 1864]. Tisk A. Landfras syn J. Hradec. 4 s., $163 \times 105 \mathrm{~mm}$. Incipit: Zastavte se malou chvíli, o vy hospodáři milí. Sbírka MJH, K 5840.

na jeden arch, kdy mohly být použity oba štočky při tisku najednou. Před polovinou 19. století pořídil Alois Landfras více než 200 ocelorytin pro výzdobu modlitební literatury. Obsahovaly rytiny titulního listu a frontispisu současně, ale také samostatné menší kovorytiny, které se užívaly jako výzdoba modlitebních knih i pro tisk svatých obrázků a kramářských tisků. Převažovaly v nich motivy ze života Panny Marie a Ježíše a další novozákonní témata a vyobrazení náboženských symbolů a alegorií, především Srdce Kristova a Mariina a symboly Kristova utrpení i motivy reflektující život věřících. V Landfrasově tiskárně je tiskli a prodávali samostatně jako svatý obrázek nebo lepili k modlitbě či písni a prodávali jako kramářský tisk. V této souvislosti je zřetelná souvislost s některými typy devoční grafiky, především svatých obrázků, domovních požehnání, tisků typu mementa mori a psaníček, a to jak v oblasti způsobů jejich výroby a prodeje, tak v oblasti jejich následného užití v domácnosti. ${ }^{60}$ Další otisky kovorytů a dřevorytů se nacházejí také v modlitební literatuře této tiskárny, především v Nebeklíčích. ${ }^{61}$

Stejně jako analýza výzdoby a zjištěné prolínání konkrétních ilustrací celým spektrem tiskařské produkce je významná i analýza výskytu jednotlivých textů. Lidová, zlidovělá i umělá píseň nebo poezie náboženského i světského obsahu se objevovala kromě kramářských tisků i v dalších tištěných médiích - v kancionálech, zpěvnících, periodikách nebo autorsky určených souborech, ale též v rukopisech. Jejich častým inspiračním zdrojem byly také modlitební knihy, v nichž se kromě modliteb a litanií objevují také duchovní písňové texty, které zde bývaly řazeny $\mathrm{v}$ samostatném oddíle.

Je patrné, že předchozí i současný stav bádání o kramářském tisku jako součásti knižní kultury i každodenního života minulých staletí v oblasti tzv. světské kramářské písně očekává v oblasti náboženských kramářských tisků své literárněvědné zhodnocení.

\section{Literatura:}

BARTOŠ 1871: BARTOŠ, František. Paběrky sebrané na poli české poesie kramářské. Časopis Matice Moravské 3, 1871, s. 6-28, 56-84.

BARTOŠ 1883: BARTOŠ, František. O světských písních kramářských. Obzor. List pro poesii a zábavu 6, 1883, s. 19-21, 289-295, 305-309, 323-326, 337-339.

BARTOŠ 1885: BARTOŠ, František. O naší poezii kramářské. In: Lid a národ. Velké Meziříčí 1885.

BCBT 2016: Bibliografie cizojazyčných bohemikálních tiski̊ do roku 1800. Praha: AV ČR, 2016. Dostupné z:

https://kvo.lib.cas.cz/cizojazycna-bohemika/bibliografie-cizojazycnych-bohemikalnich-tisku/. [Cit. 25. 5. 2021]

BĚHALOVÁ 1993: BĚHALOVÁ, Štěpánka. Kramářské tisky a tiskařské štočky s tematikou sv. Jana Nepomuckého ve sbírkách Okresního muzea v Jindřichově Hradci. In: Jindřichohradecký vlastivédný sborník 5, 1993, s. 21-45. BĚHALOVÁ 1994: BĚHALOVÁ, Štěpánka. Panna Marie Svatohorská V kramářských tiscích Okresního muzea v Jindřichově Hradci. In: Jindřichohradecký vlastivědný sbornik 6, 1994, s. 21-49.

BĚHALOVÁ 1995: BĚHALOVÁ, Štěpánka. Kramářské tisky ze sbírek Okresního muzea v Jindřichově Hradci věnované mariánským poutním místům v jižních Čechách. In: Jindřichohradecký vlastivědný sborník 7, 1995, s. 13-36. BĚHALOVÁ 1996a: BĚHALOVÁ, Štěpánka. Kramářské tisky věnované mariánským poutním místům v Čechách a na Moravě ze sbírek Okresního muzea v Jindřichově Hradci. In: Jindřichohradecký vlastivědný sbornik 8, 1996, s. $12-30$.

BĚHALOVÁ 1996b: BĚHALOVÁ, Štěpánka. Analytická sonda do sbírky původních štočků a kramářských tisků Okresního muzea v Jindřichově Hradci. Knihy a dějiny 3, 1996, č. 1, s. 21-32.

BĚHALOVÁ 1997a: BĚHALOVÁ, Štěpánka. Poutní místa v zahraničí a sbírka kramářských tisků Okresního muzea v Jindřichově Hradci. In: Jindřichohradecký vlastivědný sbornik 9, 1997, s. 10-31.

BĚHALOVÁ 1997b: BĚHALOVÁ, Štěpánka. 200 let Landfrasovy tiskárny 1797-1997. Katalog výstavy. Jindřichův Hradec: Okresní muzeum, 1997.

\footnotetext{
${ }^{60}$ KAFKA 2009; BĚHALOVÁ 2012, zejména s. 15, 18,20, 23, 29, 35, 43-47; BĚHALOVÁ 2013.

${ }^{61}$ BĚHALOVÁ 2017.
} 
BĚHALOVÁ 1997c: BĚHALOVÁ, Štěpánka. Nejnovější přrirustky do sbírky knižní kultury. Novum 6, 1997, č. 7, s. 2. BĚHALOVÁ 1998: BĚHALOVÁ, Štěpánka. Jindřichův Hradec (Neuhaus). Okresní muzeum - knihovna (Bezirksmuseum - Bibliothek). In: Handbuch Deutscher Historischer Buchbestände in Europa. Band 2. Tschechische Republik. Hildeshei Zürich - New York: Olms-Weidman, 1998, s. 67-69.

BĚHALOVÁ 2001: BĚHALOVÁ, Štěpánka. Náboženský kramářský tisk se zvláštním zřetelem k jindřichohradecké Landfrasově tiskárně. Praha: Filozofická fakulta UK, 2001. Disertační práce. Univerzita Karlova. Filozofická fakulta.

BĚHALOVÁ 2003: BĚHALOVÁ, Štěpánka. Náboženský kramářský tisk a jeho recepce. In: $K$ výzkumu zámeckých, měštanských a církevních knihoven Čtenár a jeho knihovna. České Budějovice: Jihočeská univerzita, 2003, s. 547-558.

BĚHALOVÁ 2006: BĚHALOVÁ, Štěpánka. Das Echo der Wallfahrten in der Produktion der Jahrmarktsdrucke (Am Beispiel der Druckerei Landfras aus Jindřichův Hradec/Neuhaus). In: Wallfahrten in der europäischen Kultur=Pilgrimage in Eropean Culture. Frankfurt am Main 2006, s. 655-671.

BĚHALOVÁ 2008: BĚHALOVÁ, Štěpánka. Odraz ženy v kramářských tiscích z jindřichohradecké Landfrasovy tiskárny. In: HOLUBOVÁ, Markéta et al. Obrazy ženy v kramáršké produkci. Praha: Etnologický ústav AV ČR, 2008.

BĚHALOVÁ 2012: BĚHALOVÁ, Štěpánka. Obrázky z pouti. Svaté obrázky ze sbirek Muzea Jindřichohradecka. Jindřichův Hradec: Muzeum Jindřichohradecka, 2012.

BĚHALOVÁ 2013: BĚHALOVÁ, Štěpánka. Pozdvihni se duše z prachu... Kramářské tisky s náboženskou tematikou ze sbirrek Muzea Jindřichohradecka. Jindřichův Hradec: Muzeum Jindřichohradecka, 2013.

BĚHALOVÁ 2017a: BĚHALOVÁ, Štěpánka. Cesta duchovní písně Pozdvihni se duše z prachu z kramářského tisku do kancionálu. Acta Musei Nationalis Pragae - Historia Litterarum 62, 2017, č. 1-2, s. 58-64.

BĚHALOVÁ 2017b: BĚHALOVÁ, Štěpánka. Nebeklíče od Landfrasư. Knižni bestsellery 19. století. Jindřichův Hradec: Muzeum Jindřichohradecka, 2017.

BĚHALOVÁ 2018: BĚHALOVÁ, Štěpánka. Produkce Landfrasovy tiskárny a nakladatelství v 19. století. Acta Musei Nationalis Pragae - Historia Litterarum 63, 2018, č. 3-4, s. 154-176.

BĚHALOVÁ 2019: BĚHALOVÁ, Štěpánka. Kramářské tisky s adventními a vánočními písněmi a scénou narození Ježíše Krista z Jindřichova Hradce. In: Betlémy stále živé III. Jindřichův Hradec: Muzeum Jindřichohradecka, 2019, s. $252-268$.

BĚHALOVÁ - FÜRBACH 2015: BĚHALOVÁ, Štěpánka - FÜRBACH, František. Nezapomenutelné osobnosti v historii města Jindřichův Hradec. Jindřichův Hradec: Město Jindřichův Hradec, 2015.

BENEŠ 1970: BENEŠ, Bohuslav. Světská kramářská piseň. Brno: Univerzita J. E. Purkyně, 1970.

BENEŠ 1983: BENEŠ, Bohuslav. Poslyšte pisničku hezkou. Praha: Mladá fronta, 1983.
BENEŠ 1995: BENEŠ, Bohuslav. Náboženská tematika a světci v kramářských tiscích a písních. In: Světci v lidové tradici. Uherské Hradiště: Slovácké muzeum, 1995, s. 179-184.

BENEŠ 1998: BENEŠ, Bohuslav. Kramářské písně na jihozápadní Moravě. In: BĚHALOVÁ, Štěpánka (ed.). Tiskárny a tisky 19. stoleti: sborník přispěvků z celostátni konference pořádané při př́ležitosti 200. výroči založení jindřichohradecké Landfrasovy tiskárny. Jindřichův Hradec: Okresní muzeum v Jindřichově Hradci, 1998, s. 79-83.

BEZDĚK - RYŠAVÁ 1983: BEZDĚK, Karel - RYŠAVÁ, Eva. České kramářské písňové tisky, jejich bibliografické zpracování a ukázka bibliografie 19. století. Sborník Národního muzea, řada C-Literární historie 28, 1983, č. 4, s. 173-199.

BIBLIOGRAFIA 1996: Bibliografia jarmočných a pútových tlači 18. a 19. storočia z územia Slovenska. Martin: Matica slovenská, 1996.

BRIDELIUS 2012: BRIDELIUS, Fridrich. Jesličky. Staré nové pisničky. Praha, 1658; nově vydáno v KOSEK, Pavel SLAVICKÝ, Tomáš - ŠKARPOVÁ, Marie (ed.). Brno, 2012.

BYDŽOVSKÁ 2010: BYDŽOVSKÁ, Iva. Mariánská poutní místa v kramářských tiscích. In: KUBÍČEK, Jaromír (ed.). Sdruženi knihoven České republiky 2010. Brno: Sdružení knihoven ČR 2010.

BYDŽOVSKÁ 2012: BYDŽOVSKÁ, Iva. Digitální knihovna kramářských tiskủ Špalíček. In: KRUŠINSKÝ, Rostislav (ed.). Problematika historických a vzácných knižnich fondù 2011. Olomouc - Brno, 2012, s. 29-38.

ČERMÁKOVÁ 2017: Marta ČERMÁKOVÁ. Osobnosti kolem kramářských písní. Acta Musei Nationalis Pragae Historia litterarum 62, 2017, č. 1-2, s. 93-94.

FIALA 1992: FIALA, Jiří. Knižní edice českých kramářských písní. In: Kultura - Společnost - Tradice. IV. Hudebni a taneční folklor v edični praxi. Praha: Etnologický ústav AV ČR, 2011, s. 81-90.

FROLCOVÁ 2013: FROLCOVÁ, Věra. Etnomuzikologie, slavistika a mezioborová hymnologie. $\mathrm{K}$ možnostem integrovaného bádání o lidové písni z české a středoevropské perspektivy. Acta Ethnologica Danubiana 15, 2013, s. $149-160$.

HAIS 1985: HAIS, František. Vzpominky pražského pisničkáŕe 1818-1897. Praha: Odeon, 1985.

HOLUBOVÁ 2003: HOLUBOVÁ, Markéta. Tištěná poutní produkce a její čtenáŕ konzument. In: RADIMSKÁ, Jitka (ed.). $K$ výzkumu zámeckých, měštanských a cirkevních knihoven „Čtenár a jeho knihovna“. České Budějovice: Jihočeská univerzita, 2003, s. 359-568.

HOLUBOVÁ 2008: HOLUBOVÁ, Markéta (ed.). Obrazy ženy v kramářské produkci. Praha: Akademie věd České republiky, Etnologický ústav AV ČR, 2008.

HOLUBOVÁ - KOPALOVÁ 2008: HOLUBOVÁ, Markéta - KOPALOVÁ, Ludmila. Katalog kramářských tiski̊. Praha: Etnologický ústav AV ČR, 2008.

HOLUBOVÁ 2012: HOLUBOVÁ, Markéta. Katalog kramářských tiski̊ II. Biblická a křestanská ikonografie. Praha: Etnologický ústav AV ČR, 2012. 
HOLUBOVÁ 2014: HOLUBOVÁ, Markéta. Odraz kultu Panny Marie Svatohorské $\mathrm{v}$ kramářské produkci. In: HOLUBOVÁ, Markéta - SUCHOMELOVÁ, Marcela (edd.). Salve Regina. Mariánská úcta ve středních Čechách. Praha: Etnologický ústav AV ČR ve spolupráci se Státním oblastním archivem v Praze, 2014, s. 59-79.

HOLUBOVÁ 2017a: HOLUBOVÁ, Markéta. Katalog kramářských tiski̊ III. Německé kramářské tisky, jednolisty a kuplety. Praha: Etnologický ústav AV ČR, 2017.

HOLUBOVÁ 2017b: HOLUBOVÁ, Markéta. Internetová databáze kramářských tisků Etnologického ústavu Akademie věd České republiky, v. v. i., v Praze. Muzeológia a kultúrne dedičstvo 5, 2017, č. 1, s. 147-158.

IVÁNEK 2017: IVÁNEK, Jakub. Poznámky k vymezení pojmu kramářská píseň: (s ohledem na tisky náboženské povahy). Listy filologické 140, 2017, č. 1-2, s. 201-230.

KAFKA 2005: KAFKA, Luboš. Malované na skle. Lidové podmalby. Praha: LIKA KLUB, 2005.

KAFKA 2009: KAFKA, Luboš. Dárek z pouti. Poutní a poutové umění. Praha: Lika klub, Etnologický ústav Akademie věd České republiky, 2009.

KAFKA - MEVALDOVÁ 2015: KAFKA, Luboš MEVALDOVÁ, Helena. Na dřevě malované. Náboženská výzdoba lidového nábytku. Praha: Lika klub, 2015.

KALISTA 2001: KALISTA, Zdeněk. Česká barokní pout'. Žd'ár nad Sázavou, 2001.

KNIHOVĚDA 2021: Knihověda.cz Portál k dějinám české knižní kultury do roku 1800. Dostupné z: https://www.knihoveda.cz/ [Cit. 25. 5. 2021]

KNIHOPIS 1939-1967: Knihopis českých a slovenských tisků od doby nejstarší až do konce XVIII. století. Díl II. Praha, 1939-1967.

KPS KNIHOPIS: KPS KNIHOPIS. Databáze obsahuje bibliografické záznamy českojazyčných starých tiski̊ vydaných v letech 1501-1800 a také bohemikálnich inkunábulí, jež byly vytištěny na území Čech mezi lety 1476-1500. Dostupné z: https://aleph.nkp.cz/F/?func=file\&file_na$m e=$ find- $b \&$ local_base $=K P S[$ Cit. 25. 5. 2021]

KRAMÁŘSKÉ PÍSNĚ BRNO 2019-2022: Kramářské pisně v brněnských historických fondech. Dostupné z: https://www.phil.muni.cz/kramarskepisne [Cit. 25. 5. 2021]

MALURA 1999: MALURA, Jan, Slaviček rájský Jana Josefa Božana a česká duchovní píseň vrcholného baroka. In: MALURA, Jan - KOSEK, Pavel (edd.). BOŽAN, Jan Josef. Slaviček rájský. Brno: Host 1999, s. 5-43.

MUK 1940a: MUK, Jan. Špalíčkové písničky z Landfrasovy tiskárny v J. Hradci. Ohlas od Nežárky 70, 1940, č. 24-28, s. 1-2. Dostupné z: https://kramerius.mjh.cz/unid/unid:76940955-435f-11dd-b505-00145e5790ea. MUK 1940b

MUK 1940b: MUK, Jan. Špalíčkové písničky z Landfrasovy tiskárny v J. Hradci. In: Z minulosti Jindřichohradecka. Jindřichův Hradec: Přátelé starého Jindř. Hradce, 1940.

MUZEUM ČESKÉHO RÁJE 2021a: KULÍŠKOVÁ, Alžběta. Pozůstalost J. V. Scheybala. Dostupné z: https:// www.muzeum-turnov.cz/pozustalost-j-v-scheybala/ [Cit. 28. 5. 2021]

MUZEUM ČESKÉHO RÁJE 2021b: JAKUBÍČKOVÁ, Kateřina. Grantový projekt Scheybalova sbírka. Dostupné z: https://www.muzeum-turnov.cz/grantove_projekty/scheybalova-sbirka/ [Cit. 28. 5. 2021]

NOVOTNÝ 1940: NOVOTNÝ, Miloslav. Špaliček pisniček jarmarečních. Praha: Evropský literární klub, 1940. PÍSKOVÁ 2002: PÍSKOVÁ, Milada. K informativní složce kramářských tisků. In: Problematika historických a vzácných knižních fondu Čech, Moravy a Slezska 2002. Brno: Sdružení knihoven ČR, 2002, s. 71-75.

ŠPALÍČEK 1940: NOVOTNÝ, Miloslav (ed.). Špaliček pisniček jarmarečnich. Praha: Evropský literární klub, 1940. PROVENIO 2021: PROVENIO, Hlava Rudolf. Dostupné z: https://provenio.net/records/366c4b38-5665-42e7-bbbf-9d$3 d f 227130 d$ [Cit. 28. 5. 2021]

RYŠAVÁ 1997: RYŠAVÁ, Eva. Zieglerův Dobroslav, společenská píseň a kramářské tisky. In: PETRBOK, Václav TYDLITÁT, Jan (edd.). Východočeské Athény a Josef Liboslav Ziegler: sborník př́spěvkì se sympozia, Rychnov nad Kněžnou, květen 1997. Boskovice: Albert, 1997, s. 162-169.

RYŠAVÁ 1998a: RYŠAVÁ, Eva. Národní retrospektivní bibliografie kramářských písnových tisků 19. století. In: BĚHALOVÁ, Štěpánka (ed.). Tiskárny a tisky 19. stoleti: sbornik príspěvki̊ z celostátní konference pořádané při př́ležitosti 200. výroči založení jindřichohradecké Landfrasovy tiskárny. Jindřichův Hradec: Okresní muzeum v Jindřichově Hradci, 1998, s. 25-28.

RYŠAVÁ 1998b: RYŠAVÁ, Eva. K obsahové stránce kramářských písní z Landfrasovy tiskárny. In: BĚHALOVÁ, Štěpánka (ed.). Tiskárny a tisky 19. století: sborník př́spěvkù z celostátní konference pořádané při prriležitosti 200. výroči založení jindřichohradecké Landfrasovy tiskárny. Jindřichův Hradec: Okresní muzeum v Jindřichově Hradci, 1998, s. 58-60.

SEHNAL 1963: SEHNAL, Jiř́i. Nápěvy světských písní kramářských v 17. a 18. století. In: Václavkova Olomouc 1961. Praha: Státní pedagogické nakladatelství, 1963, s. 275-286. SCHEYBAL 1991: SCHEYBAL, Josef Václav. Senzace pěti století v kramářské pisni: př́spěvek $k$ dějinám lidového zpravodajského zpěvu. Hradec Králové: Kruh, 1991.

SLAVICKÝ 2008: SLAVICKÝ, Tomáš. Kramářský tisk jako hymnografický pramen - několik poznámek k repertoáru mariánských poutních písní 19. století. In: HOLUBOVÁ, Markéta (ed.). Obrazy ženy v kramářské produkci. Praha: Akademie věd České republiky, 2008, s. 169-188.

ŠPALÍČEK: ŠPALÍČEK. Digitálni knihovna kramářrských tisků. Praha: Knihovna Národního muzea. Dostupné z: http://www.spalicek.net/ [Cit. 21. 6. 2021]

ŠPALÍČEK BIBLIOGRAFIE: ŠPALÍČEK. ŠPALÍČCK digitální knihovna kramárskkých tiskì. (Praha, Knihovna Národního muzea. Dostupné z: http://www.spalicek.net/ Bibliografie.pdf/ [Cit. 28. 5. 2021]

TEPLÝ 1930: TEPLÝ, František. Z lidové četby konce XVIII. a první polovice XIX. století. (U jindřichohradecké kolébky českých tisků nové doby). Časopis pro dějiny venkova 17, 1930, s. 232-246.

TISKÁRNY A TISKY 1998: BĚHALOVÁ, Štěpánka (ed.). Tiskárny a tisky 19. století. Sbornik přispěvků z celostátní konference pořádané př̀ př́ležitosti 200. výroči založení 
jindřichohradecké Landfrasovy tiskárny. Jindřichův Hradec: Okresní muzeum v Jindřichově Hradci, 1998.

VÁCLAVEK 1947: VÁCLAVEK, Bedřich. Pisemnictví a lidová tradice: obraz jejich vztahio v české písni lidové a zlidovélé. Praha: Svoboda, $1947^{2}$.

VÁCLAVEK 1963: DVOŘÁK, Jaromír (ed.). VÁCLAVEK, Bedřich. O lidové písni a slovesnosti. Praha: Československý spisovatel, 1963.

VÁCLAVEK - SMETANA 1937: VÁCLAVEK, Bedřich SMETANA, Robert (edd.). České písně kramářské. Praha: Fr. Borový, 1937.

VÁCLAVEK - SMETANA 1950: VÁCLAVEK, Bedřich SMETANA, Robert. O české písni lidové a zlidovělé. Praha: Svoboda, 1950. Sebrané spisy Bedřicha Václavka, sv. 6.

VÁCLAVKOVA OLOMOUC 1961: Václavkova Olomouc 1961. Sbornik referátů a diskusnich přispěvků o kramářské písni. Praha: Státní pedagogické nakladatelství 1963.

VEČERKOVÁ 1995: VEČERKOVÁ, Eva. Poslouchejte, mládenci a panny... aneb o české písni kramárské. Brno: Moravské zemské muzeum, 1995.

VEČERKOVÁ 1998: VEČERKOVÁ, Eva. Pověrečné kramářské tisky ve sbírce Etnografického ústavu muzea v Brně. In: BĚHALOVÁ, Štěpánka (ed.). Tiskárny a tisky 19. století: sborník přispěvků z celostátní konference pořádané při př́ležitosti 200. výroči založení jindřichohradecké Landfrasovy tiskárny. Jindřichův Hradec: Okresní muzeum v Jindřichově Hradci, 1998, s. 84-92.

VOIT 2006: VOIT, Petr. Encyklopedie knihy: starši knihtisk a přibuzné obory mezi polovinou 15. a počátkem 19. století. Praha: Libri ve spolupráci s Královskou kanonií premonstrátů na Strahově, 2006. Bibliotheca Strahoviensis. Series monographica, 2.

WÖGERBAUER et al. 2015: WÖGERBAUER, Michael PÍŠA, Petr - ŠÁMAL, Petr - JANÁČEK, Pavel et al. $V$ obecném zájmu. Cenzura a sociální regulace literatury $v$ moderní české kultuře. Díl I-II. Praha: Academia - Ústav pro českou literaturu AV ČR, 2015.

ZACH 2008: ZACH, Aleš. Slovník českých nakladatelství [online]. 2008. Dostupné z: http://www.slovnik-nakladatelstvi.cz. [Cit. 25. 5. 2021]

\section{Štěpánka Běhalová \\ Muzeum Jindřichohradecka \\ Balbínovo náměstí 19/I \\ 37701 Jindřichův Hradec}

